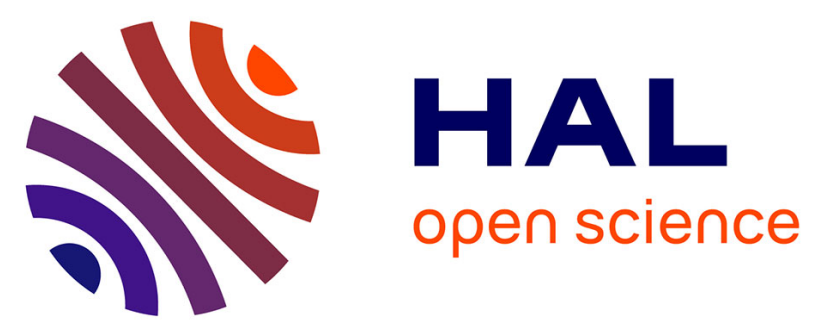

\title{
Contrasting degrees of recrystallization of carbonaceous material in the Nelson aureole, British Columbia and Ballachulish aureole, Scotland, with implications for thermometry based on Raman spectroscopy of carbonaceous material
}

Oliver Beyssac, David R. M. Pattison, Franck Bourdelle

\section{To cite this version:}

Oliver Beyssac, David R. M. Pattison, Franck Bourdelle. Contrasting degrees of recrystallization of carbonaceous material in the Nelson aureole, British Columbia and Ballachulish aureole, Scotland, with implications for thermometry based on Raman spectroscopy of carbonaceous material. Journal of Metamorphic Geology, 2019, 37 (1), pp.71-95. 10.1111/jmg.12449 . hal-02133587

\author{
HAL Id: hal-02133587 \\ https://hal.science/hal-02133587
}

Submitted on 19 May 2019

HAL is a multi-disciplinary open access archive for the deposit and dissemination of scientific research documents, whether they are published or not. The documents may come from teaching and research institutions in France or abroad, or from public or private research centers.
L'archive ouverte pluridisciplinaire HAL, est destinée au dépôt et à la diffusion de documents scientifiques de niveau recherche, publiés ou non, émanant des établissements d'enseignement et de recherche français ou étrangers, des laboratoires publics ou privés. 
2 Contrasting degrees of recrystallization of carbonaceous material in the

3 Nelson aureole, British Columbia and Ballachulish aureole, Scotland, with implications for thermometry based on Raman Spectroscopy of Carbonaceous

5 Material

8 Beyssac O. ${ }^{(1),{ }^{*}}$, Pattison D. ${ }^{(2)} \&$ Bourdelle F. ${ }^{(3)}$ 


\section{ABSTRACT}

24 The degree of recrystallization of carbonaceous material (CM), as monitored by Raman microspectroscopy, was examined as a function of metamorphic grade in two well-studied contact aureoles containing carbonaceous pelites: the aureole of the Jurassic Nelson batholith, British Columbia, and the aureole of the Silurian Ballachulish Igneous Complex, Scotland. Here, we use (i) the R2 ratio extracted from the Raman spectrum of CM as a proxy for the degree of graphitization (0.0 in perfect graphite then increasing with structural defects) and (ii) the secondorder S1 band (Ca. $\left.2700 \mathrm{~cm}^{-1}\right)$ as a marker for the tridimensional ordering of CM. The Nelson aureole (garnet-staurolite-andalusite-sillimanite-K-feldspar sequence, $\sim 550-650{ }^{\circ} \mathrm{C}, 3.5-4.0 \mathrm{kbar}$ ) was developed in rocks that were unmetamorphosed prior to contact metamorphism, whereas the Ballachulish aureole (cordierite-andalusite-K-feldspar-sillimanite sequence, $\sim 550-700{ }^{\circ} \mathrm{C}, \sim 3.0$ kbar) was developed in rocks that had been metamorphosed to garnet grade conditions ( $\sim 7 \mathrm{kbar}$, $\left.\sim 500{ }^{\circ} \mathrm{C}\right)$ c. $45 \mathrm{Ma}$ before contact metamorphism. Thirty-one samples were examined from Nelson and twenty-nine samples from Ballachulish. At Nelson, the R2 ratio steadily decreases from $\sim 0.25$ to 0.0 as the igneous contact is approached, whereas at Ballachulish the $\mathrm{R} 2$ ratio remains largely unchanged from regional values $(\sim 0.20-0.25)$ until less than $100 \mathrm{~m}$ from the igneous contact. The second-order S1 band reveals that carbonaceous material was transformed to highly 'ordered' locally tridimensional graphitic carbon at Ballachulish by regional metamorphism prior to contact metamorphism, whereas carbonaceous material was still a disordered turbostratic (bidimensional) material before contact metamorphism in the case of Nelson. Pre-texturation of carbonaceous material likely induced sluggish recrystallization of CM and delayed graphitization in the Ballachulish aureole. Temperatures of recrystallization of the carbonaceous material in the two aureoles were estimated using different published calibrations of the thermometry based on Raman Spectroscopy of Carbonaceous Material (RSCM), with differences amongst the calibrations being minor. In the Nelson aureole, temperatures are in reasonable agreement with those indicated by the metapelitic phase equilibria (all within $50^{\circ} \mathrm{C}$, most within $25^{\circ} \mathrm{C}$ ). In the Ballachulish aureole, the retarded crystallization noted above results in increasing underestimates of temperatures compared to the metapelitic phase equilibria (up to $\sim 75^{\circ} \mathrm{C}$ too low within $200 \mathrm{~m}$ of the igneous contact). Our study calls for careful attention when using RSCM thermometry in complexly polymetamorphosed rocks to assess properly the meaning of the calculated temperature. 


\section{1 / INTRODUCTION}

Carbonaceous Material (CM) is widespread in metasedimentary rocks and derives from the transformation during burial of organic matter initially trapped in sediments. In such rocks, conversion of CM (here used to describe any organic compound present in rocks) into graphite (here we used graphite to describe the crystalline form of carbon) during graphitization has been studied in many geological settings. This was done using several techniques including electron microscopy, Raman spectroscopy and X-ray diffraction (see Buseck \& Beyssac, 2014 and references therein, for a review). In the laboratory, graphitization is a process influenced by many parameters like temperature $(\mathrm{T})$, pressure $(\mathrm{P})$, time or fluid activity as shown by experiments (Beyssac, Bruno, Petitet, Goffé, \& Rouzaud, 2003a; Nakamura, Yoshino, \& SatishKumar, 2017). However, on geological timescales, the degree of graphitization, a term here used to describe the bulk physico-chemical structure of CM, is considered as a proxy for the thermal metamorphism affecting either terrestrial rocks (Wopenka \& Pasteris, 1993) or meteorites (e.g. Busemann, Alexander, \& Nittler, 2007). The degree of graphitization in metamorphic rocks is best characterized by Raman microspectroscopy because it is highly sensitive to the physicochemical transformation of carbonaceous materials (e.g., Beyssac \& Lazzeri 2012), and can be easily conducted using petrologic thin sections (polished and uncovered).

Quantitative thermometry based on Raman Spectroscopy of Carbonaceous Material (here termed RSCM thermometry) has been established by comparing the degree of graphitization as quantified by Raman spectroscopy with temperature estimates from conventional petrology (Beyssac, Goffé, Chopin, \& Rouzaud, 2002a). This initial calibration of the RSCM thermometer was developed for regional metamorphic rocks having undergone a single metamorphic event, and was later tested for contact metamorphism affecting aureoles in the vicinity of granitic intrusions (Aoya et al., 2010). The results from regional and contact metamorphism which have very different timescales of heating, suggest that time is not a controlling factor for graphitization in most metamorphic settings (Aoya et al., 2010; Hilchie \& Jamieson, 2014). This

83 transformation proceeds rapidly during metamorphism (Nakamura et al., 2017). In addition, 84 owing to the irreversible character of the graphitization 'process' and in agreement with the fact 
that graphite is the thermodynamically stable phase for most $P-T$ conditions recorded by exhumed metamorphic rocks, RSCM thermometry indicates the peak temperature during a metamorphic cycle as CM is not affected by retrogression (Beyssac et al., 2002a). The RSCM thermometer is especially useful in low grade rocks in which silicate and carbonate minerals are fine grained and provide ambiguous or poorly constrained temperature estimates, and in higher grade rocks that contain non-diagnostic mineral assemblages due to a limiting chemistry of the host rock. One unknown question is the degree to which CM recrystallizes during metamorphism if it has already been subjected to an earlier episode of metamorphism. Because the degree of recrystallization is irreversible, little if any recrystallization is expected if the temperature of the later metamorphism is lower than that of the earlier metamorphism. For the reverse situation, the question is whether recrystallization proceeds continuously once the temperature of the later metamorphism exceeds that of the earlier metamorphism.

To address this question and investigate its implications for RSCM thermometry, the degree of graphitization was examined in two well studied contact aureoles: the Nelson aureole in southeastern British Columbia, Canada (Pattison \& Vogl, 2005), and the Ballachulish aureole in the southwest Highlands of Scotland (Pattison \& Harte, 1997, and references therein). Figures 1 and 2 show maps of the Nelson and Ballachulish aureoles, respectively. The host rocks to the Nelson aureole are essentially unmetamorphosed, subgreenschist facies carbonaceous argillites, whereas the host rocks to the Ballachulish aureole are graphitic slates that had previously been regionally metamorphosed to Barrovian garnet zone (lower amphibolite facies) conditions about $45 \mathrm{Ma}$ prior to intrusion and contact metamorphism (Pattison, 2013). The part of the Nelson aureole examined in this study is the same as that analysed by Pattison and Tinkham (2009) in their study of equilibrium and kinetic controls on mineral assemblage development in contact metamorphism. In this transect, the mineral assemblage sequence is garnet-staurolite-andalusitesillimanite-K-feldspar, indicating a pressure of 3.5-4.0 kbar and a temperature range of $\sim 550{ }^{\circ} \mathrm{C}$ to $\sim 650{ }^{\circ} \mathrm{C}$. The part of the Ballachulish aureole examined in this study is the same as that analysed by Pattison (2006) in his study of the variation in abundance and textures of CM going upgrade in the aureole. In this transect, the mineral assemblage sequence is cordierite-andalusitesillimanite-K-feldspar-migmatite, indicating a pressure of 2.5-3.0 kbar and a temperature range of $\sim 550$ to $\sim 700{ }^{\circ} \mathrm{C}$. In the present study, 31 samples from Nelson and 29 samples from Ballachulish were analysed by RSCM and combined with observations on the microtextural 
116

117

118

119

120

121

122

123

124

125

126

127

128

129

130

131

132

133

134

135

136

137

138

139

140

141

142

143

144

145

146

evolution of the $\mathrm{CM}$ in the aureoles. Results from the two aureoles are synthesized, and then implications for RSCM thermometry are discussed based on these results and existing literature.

\section{2 / RSCM THERMOMETRY AND METHODOLOGY}

\section{1 / Graphitization in metamorphism and RSCM thermometry}

During diagenesis and metamorphism, CM present in the initial sedimentary rock is progressively transformed into graphite (see Buseck \& Beyssac, 2014 for a review). During burial in sedimentary basins, the thermally-induced maturation or 'cracking' of organic matter generates hydrocarbons, oil then gas, and leaves a solid residue called kerogen. This solid residue is carbon-rich as most heteroatoms $(\mathrm{H}, \mathrm{O}, \mathrm{N}, \mathrm{S})$ have been released, and it has initiated the development of an aromatic skeleton consisting of a network of six-membered, planar rings of carbon. This solid residue, if subjected to further heating during metamorphism, will be subject to graphitization sensu stricto, which consists mostly in the polymerization and structural rearrangement of the aromatic skeleton towards the thermodynamically stable $\mathrm{ABAB}$ layered sequence of graphite. The corresponding progressive evolution of the degree of graphitization is considered to be a reliable indicator of metamorphic temperature (Wopenka \& Pasteris, 1993; Beyssac et al., 2002a). Because of the irreversible character of graphitization (CM tends towards the thermodynamically stable phase which is graphite), CM structure is not sensitive to the retrograde path of the rock up to the surface, and therefore records peak metamorphic conditions (Beyssac et al., 2002a).

Raman microspectroscopy is ideally suited to the study of natural CM in situ within uncovered, polished thin sections. The first-order Raman spectrum of disordered CM exhibits a graphite $\mathrm{G}$ band at $1580 \mathrm{~cm}^{-1}, \mathrm{E}_{2 \mathrm{~g} 2}$ mode corresponding to in-plane vibration of aromatic carbons, and several defect bands (D1, D2, D3) corresponding to 'physico-chemical defects' (see Beyssac \& Lazzeri, 2012 and references therein). The structural organization of CM can be quantified through the R2 parameter, defined as the relative area of the main defect band D1 (R2 $=\mathrm{D} 1 /[\mathrm{G}+\mathrm{D} 1+\mathrm{D} 2]$ peak area ratio). A linear correlation between this R2 parameter and metamorphic temperature was calibrated using samples from different regional metamorphic belts with well-known $P-T$ conditions spanning a temperature range of 330 to $640^{\circ} \mathrm{C}$, giving rise 
to RSCM thermometry (Beyssac et al., 2002a). RSCM thermometry can be applied to metasediments of various lithologies. The uncertainty on temperature is $\pm 50^{\circ} \mathrm{C}$ mainly due to uncertainties on petrologic data used for the calibration. However, Beyssac, Bollinger, Avouac, and Goffé (2004) showed that this technique might be used to detect intersample relative variations as small as $10-15^{\circ} \mathrm{C}$, allowing for a precise estimate of thermal metamorphic gradients. $\mathrm{CM}$ exhibits second-order features in the Raman spectrum corresponding to combination and overtone scattering (see Beyssac \& Lazzeri, 2012 for review). The second-order region provides information on the tridimensional stacking order of graphitic CM. When turbostratic (imperfect stacking of the aromatic layers yielding bidimensional stacking) graphitic carbon reaches the threedimensional structure of graphite (ABAB stacking sequence), the main second order band at $\sim 2700 \mathrm{~cm}^{-1}$, corresponding to a multiple of the D1 band and here called the S1 band becomes asymmetric and can be decomposed in two bands centered around 2690 and $2730 \mathrm{~cm}^{-1}$ respectively (see Lespade, Marchand, Couzi, \& Cruege, 1984 ; Bernard et al.,, 2010 ; Beyssac \& Lazzeri, 2012).

\section{2 / Raman spectroscopy: Methodology}

Raman spectra were obtained at Institut de Minéralogie, Physique des Matériaux et Cosmochimie (Paris, France) using a Renishaw InVia Raman microspectrometer. We used the $514.5 \mathrm{~nm}$ wavelength of a Modulaser argon laser. The laser incident beam was polarized circularly by a quarter wavelength plate placed before the microscope. The laser was focused on the sample by a DMLM Leica microscope with a 100 magnification objective (Numerical Aperture $=0.85)$ and the spot size at the sample surface is around $1 \mu \mathrm{m}$ in diameter. The laser power at the sample surface was set below $1 \mathrm{~mW}$ using neutral density filters. The Rayleigh diffusion was eliminated by notch filters and the signal was finally dispersed using a $1800 \mathrm{gr} / \mathrm{mm}$ grating and analyzed by a Peltier cooled RenCam CCD detector. Before each session the spectrometer was calibrated with a silicon standard.

Because Raman spectroscopy of CM can be affected by several analytical mismatches, we followed closely the analytical and fitting procedures described by Beyssac, Petitet, Froigneux, Moreau, and Rouzaud (2003b) and Beyssac \& Lazzeri (2012). Measurements were done on polished thin sections cut perpendicularly to the bedding and/or schistosity. CM, being 
black, has a very high extinction coefficient for visible light and therefore Raman spectroscopy only probes a thin (100s of $\mathrm{nm}$ thick) surface layer of CM which makes this technique highly sensitive to the surface state of the sample. As RSCM is controlled by defects in CM, it is important to avoid any possible sample preparation bias such as structural defects induced by polishing. Therefore, CM was systematically analyzed below a transparent adjacent mineral, generally quartz, to avoid any polishing-induced artefact on the structure of CM. In metamorphic settings, especially in the case of contact metamorphic settings where $\mathrm{CM}$ can exhibit high degrees of graphitization and very fine-grained microtextures, polished petrologic thin sections must be used rather than polished rock chips. Using polished thin sections is the only way to use both transmitted and reflected light to make sure that the CM target is at depth and not at the sample surface.

To gain insight on the within-sample structural heterogeneity, at least 15-20 Raman spectra were recorded per sample. However, some samples exhibited a rather high structural heterogeneity and required acquisition of more spectra. Importantly, detrital graphitic carbon was found locally in both of the aureoles examined. The presence of detrital graphite is common because graphite is easily recycled during the erosion/weathering cycle (see Galy, Beyssac, France-Lanord, \& Eglinton, 2008). It can be easily distinguished from organic matter that is undergoing in situ graphitization based on: (i) morphological criteria - it generally appears as isolated grains or flakes; and (ii) Raman spectra - it usually exhibits a high crystallinity except in very high-grade samples where it is difficult to distinguish from the metamorphosed organic matter based on Raman spectroscopy alone. Detrital graphite spectra were not included in RSCM temperature determination. Spectra were then processed using the software Peakfit following the procedure described in Beyssac et al. (2003b) and Beyssac and Lazzeri (2012).

\section{3 / THERMODYNAMIC MODELLING}

$P-T$ estimates of isograds in the Nelson aureole were made by Pattison and Tinkham (2009), and in the Ballachulish aureole by Pattison (1989) and Pattison (2006). These estimates were based on phase equilibria modelling that used different thermodynamic datasets and, in the case of Nelson, did not incorporate the effects of graphite. In this study we have recalculated the phase 
equilibria using a single set of thermodynamic data and mineral activity-composition models and have incorporated the effects of graphite.

For Nelson, the bulk composition used for the modelling is the average Nelson carbonaceous argillite composition (p. 71-72 of Pattison \& Vogl, 2005 and Table 1 of Pattison \& Tinkham, 2009), whereas for Ballachulish, the bulk composition is the average composition of the carbonaceous slates of Ballachulish Slate-Transition Series (Table 1 and Appendix 2 of Pattison, 2013). Both compositions are listed in Table 1 of this paper. The thermodynamic modelling was done in the model chemical system MnNCKFMASHT $\left(\mathrm{MnO}-\mathrm{Na}_{2} \mathrm{O}-\mathrm{CaO}-\mathrm{K}_{2} \mathrm{O}-\mathrm{FeO}-\mathrm{MgO}-\right.$ $\mathrm{Al}_{2} \mathrm{O}_{3}-\mathrm{SiO}_{2}-\mathrm{H}_{2} \mathrm{O}-\mathrm{TiO}_{2}$ ), in which $\mathrm{C}, \mathrm{P}_{2} \mathrm{O}_{5}$ and LOI (loss on ignition) were omitted from the raw whole-rock analysis. All Fe was treated as $\mathrm{Fe}^{2+}$, in respect of the relatively reducing nature of the carbonaceous rocks. All mineral assemblages of interest to this study developed under subsolidus conditions, so excess $\mathrm{H}_{2} \mathrm{O}$ was assumed. The presence of graphite in the rocks results in small concentrations of carbon-bearing fluid species in the metamorphic fluid, lowering $\mathrm{a}_{\mathrm{H} 2 \mathrm{O}}$. This effect was incorporated into the phase equilibria modelling following the approach of Connolly and Cesare (1993).

The phase diagrams were calculated using the phase equilibria modelling software program Theriak-Domino (de Capitani \& Brown, 1987; de Capitani \& Petrakakis, 2010). The thermodynamic dataset used to calculate the phase diagrams is that of Holland and Powell (1998), updated to version ds5.5. The activity-composition (a-x) relations used in conjunction with ds5.5 comprise the following: garnet and chlorite, Tinkham et al. (2001); biotite, White et al. (2005); plagioclase, Holland and Powell (2003; ternary feldspar, Cbar1 field); white mica, Coggon and Holland (2002; margarite component omitted); ilmenite, Tinkham and Ghent (2005; ideal ternary); melt, White et al. (2007); all other phases including $\mathrm{H}_{2} \mathrm{O}$, Holland and Powell (1998). Use of the 2007 'Thermocalc331' a-x relations

(http://www.metamorph.geo.uni-mainz.de/thermocalc/software/index.html) with dataset ds5.5, or use of the Holland and Powell (2011) dataset ds6.2 with the a-x models of White et al. (2014a, 2014b), result in poorer models of low-pressure subsolidus metapelitic phase equilibria, as discussed in Pattison and DeBuhr (2015). Even with the preferred dataset and a-x models, some aspects of the modelled phase equilibria do not match the natural constraints (discussed in more 
238 detail below), but these disparities do not compromise the key temperature constraints in the two 239 aureoles.

\section{4 / GEOLOGICAL BACKGROUND}

\section{1 / The Nelson Batholith and aureole}

\subsection{1 / Local geology}

The Nelson Batholith (Figure 1a) is one of the largest of a suite of middle Jurassic plutons, known as the Nelson suite, in southeastern British Columbia (e.g., Archibald, Glover, Price, Carmichael, \& Farrar, 1983). The batholith is emplaced in Triassic-Jurassic carbonaceous argillaceous rocks of the Ymir and Slocan groups that were essentially unmetamorphosed (subgreenschist facies) prior to intrusion of the Nelson suite (Powell \& Ghent, 1996; Morgan, 2016; Starr, 2017). The composite batholith ranges from tonalite to granite and comprises a northern mass, including the Mt. Carlyle Stock, of about 30 x $50 \mathrm{~km}^{2}$ (referred to as the main body) and a $25 \mathrm{~km}$ long southern 'tail' (Little, 1960; Vogl \& Simony, 1992) (Figure 1a). U-Pb dating indicates that the different phases of the batholith were intruded in the Jurassic between $c$. 173 and 159 Ma (Parrish, 1992; Sevigny \& Parrish, 1993; Ghosh, 1995). Geophysical and petrological data suggest that the northern mass of the batholith is a tabular, flat-bottomed body,

2582 to $7 \mathrm{~km}$ below present-day sea level (Cook et al., 1988), whereas the southern 'tail' of the batholith, which is the focus of this study, shows sub-vertical contacts with the host rocks (Vogl \& Simony, 1992) development of porphyroblasts of cordierite, staurolite or andalusite. U-Pb dating of monazite produced during contact metamorphism is the same age, within error, as the intrusion (Tomkins \& Pattison, 2007). As shown in Figure 1a, higher pressure staurolite \pm andalusite-bearing mineral assemblage sequences are restricted to the aureole surrounding the east half of the batholith whereas lower pressure cordierite \pm andalusite-bearing mineral assemblage sequences are restricted to the aureole surrounding the west half of the batholith and its northern and southern tips (Pattison \& Vogl, 2005). These data indicate that the batholith and aureole are tilted $\sim 10$ 
269 degrees to the west, with the tilting ascribed to a combination of Jurassic-Cretaceous 270 contractional deformation and Eocene extension (Pattison \& Vogl, 2005). Figure 1b,c show the 271 part of the aureole examined in this study, with Figure $1 \mathrm{~b}$ corresponding to Area D of Pattison 272 and Vogl (2005). Area D was studied in further detail by Pattison and Tinkham (2009), and the 273 isograds in Figure 1b come from this latter study.

274

275 276

277 278 279 280 281

282 283 284 285 286

287 288 289 290 291 292 293 294 295 296 297

\subsection{2 / Isograds}

The sequence of mineral-in isograds in the study area is: garnet; staurolite \pm andalusite; sillimanite; K-feldspar (Figure 1b). The garnet and staurolite \pm andalusite isograds are nearly coincident. The above prograde sequence classifies as facies series $2 \mathrm{~b}$ (staurolite-andalusite) in the scheme of Pattison and Tracy (1991).

Two major dehydration intervals in the isograd sequence correspond to the consumption of chlorite and muscovite, respectively. The first interval, involving chlorite consumption, is associated with the closely spaced garnet, staurolite and andalusite isograds, $\sim 1400 \mathrm{~m}$ from the contact. The idealized reactions introducing these porphyroblasts, written in the model KFMASH chemical system, are, respectively (abbreviations of Kretz, 1983):

$$
\begin{aligned}
& \mathrm{Ms}+\mathrm{Chl}+\mathrm{Qtz}=\mathrm{Grt}+\mathrm{Bt}+\mathrm{H}_{2} \mathrm{O} \\
& \mathrm{Ms}+\mathrm{Grt}+\mathrm{Chl}+\mathrm{Qtz}=\mathrm{St}+\mathrm{Bt}+\mathrm{H}_{2} \mathrm{O} \\
& \mathrm{Ms}+\mathrm{St}+\mathrm{Chl}=\mathrm{And}+\mathrm{Grt}+\mathrm{Bt}+\mathrm{Qtz}+\mathrm{H}_{2} \mathrm{O} \\
& \mathrm{Ms}+\mathrm{St}+\mathrm{Qtz}=\mathrm{And}+\mathrm{Grt}+\mathrm{Bt}+\mathrm{H}_{2} \mathrm{O}
\end{aligned}
$$

(The prefix ' $\mathrm{N}$ ' in the reaction numbering is used to distinguish numbered reactions in the Nelson aureole from those in the Ballachulish aureole). However, the lack of textural evidence for the participation of garnet in reaction N2 and of staurolite in reactions N3 and N4 (ie, lack of evidence for dissolution) in the vicinity of the isograds suggests that all three porphyroblasts developed from reaction of matrix minerals (Pattison \& Tinkham, 2009). The reactions producing staurolite and andalusite were therefore interpreted to be:

$$
\begin{aligned}
& \mathrm{Ms}+\mathrm{Chl}+\mathrm{Qtz}=\mathrm{St}+\mathrm{Bt}+\mathrm{H}_{2} \mathrm{O} \\
& \mathrm{Ms}+\mathrm{Chl}=\mathrm{And}+\mathrm{Bt}+\mathrm{Qtz}+\mathrm{H}_{2} \mathrm{O}
\end{aligned}
$$


298 Pattison and Tinkham (2009) ascribed the clustering of the garnet, staurolite and andalusite 299 isograds to a 'cascade effect' triggered by the overstepped, kinetically-delayed nucleation and 300 growth of garnet and concomitant release of fluid.

302 The second major dehydration reaction in the aureole is associated with the development of co303 existing sillimanite and K-feldspar and the loss of primary (foliation-defining, as opposed to 304 alteration-related) muscovite :

$305 \mathrm{Ms}+\mathrm{Qtz}=\mathrm{Sil}+\mathrm{Kfs}+\mathrm{H}_{2} \mathrm{O}$

306 In some samples K-feldspar occurs in medium-coarse grained leucosomes (Figure 6g of Pattison $307 \&$ Vogl, 2005), suggesting that reaction N7 locally may have been a partial melting reaction such 308 as:

$$
\mathrm{Ms}+\mathrm{Pl}+\mathrm{Qtz}=\mathrm{Sil}+\mathrm{Kfs}+\text { melt }
$$

Between these two major dehydration intervals are a number of other isograds. The sillimanite

312 isograd occurs $\sim 400 \mathrm{~m}$ from the intrusive contact and is marked by small amounts $(<<1$ modal $313 \%$ ) of fibrolitic and fine-grained sillimanite that occurs in the matrix and on the margins of 314 andalusite and staurolite porphyroblasts. Three hundred metres from the contact, staurolite 315 decreases markedly and sillimanite increases markedly, shown on Figure $1 \mathrm{~b}$ as the "major 316 staurolite-out, sillimanite-in' isograd. Combined with evidence for a second generation of garnet 317 growth, this latter change is ascribed to the reaction:

$$
\mathrm{Ms}+\mathrm{St}+\mathrm{Qtz}=\mathrm{Sil}+\mathrm{Grt}+\mathrm{Bt}+\mathrm{H}_{2} \mathrm{O}
$$

319 The delayed progress of the staurolite-consuming reaction in most of the rocks, producing 320 sillimanite (reaction N9) rather than andalusite (reaction N4), was ascribed to the small free 321 energy change of the reaction and a change in the nucleation kinetics arising from the 322 development of sillimanite (Pattison \& Tinkham, 2009, p. 276).

\subsection{3 / Pressure of contact metamorphism and isograd temperatures}

326 Figure 3a shows a phase diagram calculated for the average Nelson carbonaceous argillite. The 327 isograd sequence in the aureole (garnet; staurolite \pm andalusite; sillimanite; K-feldspar) is possible 
within the range 3.3-4.0 kbar. The clustered staurolite-in and andalusite-in isograds favour a pressure at the lower end of this range, $3.5 \mathrm{kbar}$ (see also Pattison \& Tinkham, 2009).

The temperatures of the isograds in the Nelson aureole are based on the $3.5 \mathrm{kbar}$ isobaric transect through the phase diagram in Figure $3 \mathrm{a}$. They are $3-8^{\circ} \mathrm{C}$ lower than those in Table 2 of Pattison and Tinkham (2009), due to lowered $\mathrm{a}_{\mathrm{H} 2 \mathrm{O}}$ in the hydrous fluid phase because of CM in the rocks, a factor that was not taken into account in the earlier study.

The two reaction isograds that anchor the temperature profile in the Nelson aureole are the chlorite-consuming, staurolite/andalusite-producing reaction isograd and muscoviteconsuming, sillimanite $+\mathrm{K}$-feldspar-producing reaction isograd. Concerning the chloriteconsuming reactions, the staurolite- or andalusite-producing reactions (reactions N2 to N6), whether stable or metastable, cluster in a small, $<10{ }^{\circ} \mathrm{C}$ interval, centred on $555{ }^{\circ} \mathrm{C}$, shown as an open circle in Figure 3a. Because they are all high-entropy reactions, they will be least affected by any possible overstepping (Pattison, de Capitani, \& Gaidies, 2011). Over the pressure range of contact metamorphism of 3.3-4.0 kbar (Pattison \& Tinkham, 2009), reactions N2 to N6 occur in the range $550-570^{\circ} \mathrm{C}$. Incorporating some further uncertainty arising from uncertainty in the thermodynamic data, the preferred estimate for the chlorite-consuming, garnet/staurolite/andalusite-producing reaction isograd is $555 \pm 20{ }^{\circ} \mathrm{C}$. For the muscoviteconsuming reaction isograd (reaction N7), the estimated temperature at $3.5 \mathrm{kbar}$ is $645^{\circ} \mathrm{C}$ (open circle in Figure 3a). Over the pressure range of 3.3-4.0 kbar, the temperature range is $640-660{ }^{\circ} \mathrm{C}$ (Figure 3a), which combined with some thermodynamic uncertainty results in an estimate of 645 $\pm 20{ }^{\circ} \mathrm{C}$ for this reaction isograd.

The other isograd reactions in the aureole do not provide robust constraints on temperature. As noted above, the staurolite-consuming reaction (reactions N4 and N9) has been significantly overstepped, and the nature of the reaction introducing sparse sillimanite is obscure (Pattison \& Tinkham, 2009).

The temperature estimates of the chlorite-consuming and muscovite-consuming reaction isograds are combined with the distance of the isograds from the contact (Figure 1b,c) to produce a temperature vs. distance profile in Figure 4a. Temperature estimates of samples between and outside of (at lower grade than) the two anchoring reaction isograds (filled circles in Figure 3a) are interpolated by eye, guided by the gently curving shape of the temperature-distance profile in Figure 14 of Pattison and Tinkham (2009), and thus are not independent estimates. For samples 
359 between the isograds, the added temperature uncertainty arising from this interpolation method

360 will be small, probably less than $\pm 10^{\circ} \mathrm{C}$, whereas for samples at the greatest distance from the intrusive contacts, outside the chlorite-consuming reaction isograd, uncertainty arising from interpolation could increase to \pm 15 -20 ${ }^{\circ} \mathrm{C}$. Distances in Figure $4 \mathrm{a}$ and Table 2 are based on the grey section line shown in Figure 1b, with samples away from the transect interpolated into the line of section based on their position relative to the isograds, yielding uncertainties of $\pm 30 \mathrm{~m}$. Samples from Figure 1c have a larger uncertainty $( \pm 200 \mathrm{~m})$.

\subsection{4 / Temperature of host rocks outside the aureole}

Temperature estimates for the regional rocks at the time of intrusion are not well constrained. Powell and Ghent (1996), Morgan (2016) and Starr (2017) mapped a series of regional isograds in the area demonstrating an increase in metamorphic grade as the plutons of the Nelson suite

372 were approached, from prehnite-pumpellyite (subgreenschist) facies to lower amphibolite facies 373 close to the intrusive contacts. One of the isograds they mapped was a biotite-in isograd in 374 carbonaceous argillites. The lowest grade argillaceous rocks sampled in this study (Figure 1c) 375 come from the biotite zone, i.e., upgrade of this biotite isograd. Petrographic observation of these 376 rocks shows that the biotite occurs as small crystals at random orientations in the matrix, similar 377 to the grain size and texture of biotite in samples from the narrow garnet zone of the aureole. We 378 therefore interpret that the biotite in these low grade samples developed as part of the contact metamorphism associated with the Nelson intrusion, rather than being part of a separate, preintrusion, regional metamorphic biotite zone as suggested in Pattison and Vogl (2005) and Pattison and Tinkham (2009). The method of estimating temperatures of biotite-bearing samples

382 outward from (at lower grade than) the clustered garnet/staurolite/andalusite isograds in Figure $3831 \mathrm{~b}, \mathrm{c}$ is discussed above in Section 4.1.3. 
The second locality chosen is the aureole surrounding the Ballachulish Igneous Complex, Scotland (Voll, Töpel, Pattison, \& Seifert, 1991; Pattison \& Harte, 1997), illustrated in Figure 2a. The $425 \pm 4$ Ma igneous complex (Fraser, Pattison, \& Heaman, 2004) was emplaced in metasediments belonging to the Dalradian Supergroup (Pattison \& Voll, 1991). Prior to emplacement of the igneous complex, the host metasediments were subjected to two phases of penetrative deformation and were metamorphosed to Barrovian garnet-zone conditions ( $\sim 7 \mathrm{kbar}$, $\sim 500{ }^{\circ} \mathrm{C}$; Pattison, 2013) during regional orogenesis at c. $470 \mathrm{Ma}$ (Grampian phase of the Caledonian orogeny).

The intrusion consists of an outer orthopyroxene-bearing diorite shell (emplacement $\mathrm{T}$ $\sim 1100{ }^{\circ} \mathrm{C}$ ) surrounding a central body of granite (emplacement $\mathrm{T} \sim 850{ }^{\circ} \mathrm{C}$ ), the latter emplaced when the central portion of the diorite was still partially molten (Weiss \& Troll, 1989; 1991). A well-developed contact aureole surrounds the intrusive complex, ranging in width from 400 to $1700 \mathrm{~m}$, based on the outermost occurrence of cordierite 'spots' (Figure 2a). Isograds in pelitic rocks, the most abundant rock type in the aureole, can be mapped around the intrusion and range from development of cordierite up to anatectic migmatization (Pattison \& Harte, 1985; 1991; Pattison, 1989).

The contact metamorphism was mainly caused by intrusion of the diorite phase, with the later granite having little effect (Buntebarth, 1991). The duration of the contact metamorphic event, for temperatures above conditions of the cordierite-in reaction $\left(\sim 550{ }^{\circ} \mathrm{C}\right)$, is estimated to have been about $500 \mathrm{ka}$, whereas rocks in the inner aureole were hot enough to be partially molten ( $\mathrm{T}$ above $\sim 660{ }^{\circ} \mathrm{C}$ ) for about $270 \mathrm{Ka}$ (Buntebarth, 1991). With the exception of some fluid-fluxed partial melting on the west flank of the complex, fluid communication between the intrusion and aureole was generally limited (Harte et al., 1991; Ferry, 1996), with no evidence for development of a large-scale hydrothermal circulation system around the intrusion.

Carbonaceous slates and phyllites belonging to the Ballachulish Slate and Transition Series stratigraphic units (Pattison \& Voll, 1991, and references therein) occur at various places in the contact aureole (Figure 2a). The focus of this study is a band of carbonaceous metapelite that can be traced continuously upgrade along strike in the southeast part of the aureole (Figure 2b). This band of rock was the subject of a study by Pattison (2006) on the abundance and textures of carbonaceous material in the aureole, and a description of this transect is provided on pages 103-117 of the field guide of Pattison and Harte (2001). The pre-intrusion regional 
420

421

422

423

424

425

426

427

428

429

metamorphic grade is garnet zone (lower amphibolite facies), but the carbonaceous slates and phyllites themselves do not contain either garnet or biotite due to their relatively magnesian composition (Pattison, 2013).

\subsection{2 / Isograds}

Five mineral assemblage zones related to contact metamorphism, separated by four isograds, have been mapped in the carbonaceous metapelite (Pattison \& Harte, 1985; 1991). The isograds are: cordierite+biotite-in (Zone I/II isograd); chlorite-out (Zone II/III isograd); andalusite-in (Zone III/IV isograd); K-feldspar-in (Zone IV/V) isograd (Figure 2b). Within Zone V, upgrade of the K-feldspar-in isograd, sillimanite and anatectic migmatite are variably developed (Pattison \& Harte, 1988). This isograd sequence classifies as facies series 1b/1c (cordierite-andalusite) in the scheme of Pattison and Tracy (1991).

As at Nelson, the two major dehydration reaction isograds in the Ballachulish aureole correspond to the consumption of chlorite and muscovite, respectively. The consumption of chlorite occurs in a narrow interval between the closely-spaced Crd+Bt-in (Zone I/II) isograd and Chl-out (Zone II/III) isograd, and corresponds to the following reaction, written in the idealized KFMASH chemical system:

$$
\mathrm{Ms}+\mathrm{Chl}+\mathrm{Qtz}=\mathrm{Crd}+\mathrm{Bt}+\mathrm{H}_{2} \mathrm{O}
$$

(The 'B' prefix in the numbered reactions refers to reactions in the Ballachulish aureole). In the field, the width of the interval between the first appearance of $\mathrm{Crd}+\mathrm{Bt}$ and the last occurrence of primary chlorite (Zone II) is approximately $100 \mathrm{~m}$ (Figure. 2b).

The second major reaction, associated with the loss of primary muscovite and development of co-existing andalusite and metamorphic K-feldspar (Zone IV/V isograd), is:

$$
\mathrm{Ms}+\mathrm{Qtz}=\mathrm{And}+\mathrm{Kfs}+\mathrm{H}_{2} \mathrm{O}
$$

Sillimanite first develops at or a little upgrade of the first development of andalusite+K-feldspar.

Between isograd reactions B1 and B2 is a less well-constrained isograd (Zone III/IV isograd) that marks the development of andalusite in some but not all rocks (Figure 2b). The Fe$\mathrm{Mg}$ divariant reaction introducing andalusite to the $\mathrm{Crd}+\mathrm{Bt}$ assemblage is:

$$
\mathrm{Ms}+\mathrm{Crd}=\mathrm{And}+\mathrm{Bt}+\mathrm{Qtz}+\mathrm{H}_{2} \mathrm{O}
$$


450

451

452

453

454

455

456

457

458

459

460

461

462

463

464

465

466

467

468

469

470

471

472

473

474

475

476

477

478

479

480

Figure 10 of Pattison, Spear, Debuhr, Cheney, and Guidotti (2002) shows that this reaction has a shallow negative slope in $P-T$ space and is strongly dependent on bulk rock $\mathrm{Mg} /(\mathrm{Mg}+\mathrm{Fe})$, most likely accounting for its progress in only some rocks.

\subsection{3 / Pressure of contact metamorphism and isograd temperatures}

Figure $3 \mathrm{~b}$ shows a phase diagram calculated for the average Ballachulish carbonaceous argillite. The phase diagram differs from the Nelson phase diagram in Figure 3a because the Ballachulish bulk composition is more magnesian $(\mathrm{Mg} /(\mathrm{Mg}+\mathrm{Fe})=0.54$ vs. 0.42), calcic $(\mathrm{Ca} /(\mathrm{Ca}+\mathrm{Fe}+\mathrm{Mg}+\mathrm{Mn})=0.12$ vs. 0.01$)$ and aluminous $\left(\mathrm{A}^{\prime}=(\mathrm{Al}-\mathrm{Na}-2 \mathrm{Ca}-3 \mathrm{~K}) / 2=0.24\right.$ vs. 0.14$)$ than the Nelson bulk composition. The isograd sequence in the aureole (cordierite; andalusite in some bulk compositions; K-feldspar; sillimanite) does not fit simply with the predicted phase equilibria in Figure 3b. For example, assuming an isobaric $P-T$ path, passage through the MsAndBtCrd field in Figure $3 b$ (corresponding to reaction B3) requires a higher pressure than is implied by the development of sillimanite upgrade of the development of andalusite+K-feldspar. Pattison et al. (2002) and Pattison and DeBuhr (2015) discussed difficulties in thermodynamically modelling reaction B3, which is sensitive to small changes in the mineral thermodynamic parameters. We therefore place greater emphasis on the development of andalusite $+\mathrm{K}$-feldspar by reaction $\mathrm{B} 2$ than the sporadic development of $\mathrm{Ms}+\mathrm{And}+\mathrm{Crd}+\mathrm{Bt}$ by reaction $\mathrm{B} 3$, and so favour a pressure of $3.0 \mathrm{kbar}$ within a possible range of 2.7-3.3 kbar. This is the same pressure estimate as in Pattison (1989; 2006).

The temperature of the isograds in the Ballachulish aureole are based on the $3.0 \mathrm{kbar}$ isobaric transect through the phase diagram in Figure $3 \mathrm{~b}$. The two reaction isograds that anchor the temperature profile in the Ballachulish aureole are essentially the same as in the Nelson aureole, namely the chlorite-out reaction (that at Ballachulish produces cordierite; reaction B1) and the muscovite-out reaction (that at Ballachulish produces andalusite+K-feldspar; reaction B2). For a pressure of contact metamorphism of $3 \mathrm{kbar}$, the temperature of reaction B1 is $\sim 550$ ${ }^{\circ} \mathrm{C}$. For a range of pressure of $\pm 0.5 \mathrm{kbar}$, the temperature range varies by $\pm 10{ }^{\circ} \mathrm{C}$. Incorporating some further uncertainty arising from uncertainty in the thermodynamic data, the preferred estimate for reaction $\mathrm{B} 1$ is $550 \pm 20^{\circ} \mathrm{C}$. For the muscovite-consuming reaction isograd (reaction B2), the estimated tempertature at $3.0 \mathrm{kbar}$ is $\sim 625^{\circ} \mathrm{C}$. Over the pressure range of $2.5-3.5 \mathrm{kbar}$, 
481 the temperature range is $610-640{ }^{\circ} \mathrm{C}$ (Figure $3 \mathrm{~b}$ ), which combined with some thermodynamic 482 uncertainty results in an estimate of $625 \pm 20{ }^{\circ} \mathrm{C}$ for this reaction isograd. Despite using a different thermodynamic dataset, the above estimates are the same as in Pattison $(1989 ; 2006)$.

Temperatures of the highest grade rocks, between the K-feldspar-in isograd (reaction B2) and the igneous contact (Figure 2b), are constrained by the estimated contact temperature. The contact temperature in this part of the aureole is estimated to be $\sim 700{ }^{\circ} \mathrm{C}$, based on the absence of high grade mineral assemblages and evidence for dehydration melting such as found elsewhere in the aureole, limiting temperatures to less than $750{ }^{\circ} \mathrm{C}$ (Pattison, 1989). The greater degree of uncertainty on the contact temperature, compared to reaction isograds B1 and B2, yields an estimate of $700 \pm 30{ }^{\circ} \mathrm{C}$.

The temperature estimates of reactions B1 and B2 are combined with the distance of the isograds from the contact (Figure 2b) to produce a temperature vs. distance profile for Ballachulish in Figure 4b. Distances in Figure $4 \mathrm{~b}$ and Table 3 are based on the grey section lines shown in Figures 2a,b. These were chosen to be perpendicular to the trace of the isograds and the intrusive contact, rather than at an oblique orientation as followed by the line of samples in Figure 2b, and thus more closely comparable to the thermal profiles in Figure 18.12 of Buntebarth (1991) and Figure 11 of Pattison \& Harte (1997). Samples were interpolated into the line of section in Figure 2a based on their position relative to the mapped isograds, yielding uncertainties of $\pm 30 \mathrm{~m}$. Numbered samples from Figure $2 \mathrm{a}$, from well outside the aureole, have a larger uncertainty $( \pm 200 \mathrm{~m})$. Similar to Nelson, temperature estimates of samples between, and outside of, the two anchoring reaction isograds (filled circles in Figure 3b) are interpolated by eye, guided by the thermal profiles in Buntebarth (1991) and Pattison and Harte (1997), and thus are not independent estimates. The added temperature uncertainty arising from this interpolation method is thus estimated to be the same as described in Section 4.1.3 for Nelson (less than \pm 10 ${ }^{\circ} \mathrm{C}$ between isograds, less than $\pm 20^{\circ} \mathrm{C}$ outside the isograds). We note that the above estimates are not significantly compromised by possible variations in the shape or attitude of the intrusive contact as long as the mineral reactions (mapped isograds) record the variation in thermal 509 conditions experienced by the rocks in the aureole.

\subsection{4 / Temperature of host rocks outside the aureole}


512 Temperature estimates for the regional rocks outside of the aureole are based on the phase 513 equilibria and geothermobarometry constraints described in Pattison (2013) and Pattison and 514 Voll (1991) from rocks in the vicinity of the regional garnet isograd that lies a few kilometres to 515 the northwest of the sample transect (Figure 2a). These cluster around $500{ }^{\circ} \mathrm{C}$ at a pressure of 6-7 516 kbar. The gentle southeasterly-increasing regional metamorphic gradient in the host rocks to the 517 Ballachulish intrusion (Pattison, 2013) suggest that samples in the southeast of the area, upgrade 518 of the garnet isograd, may have attained slightly higher temperatures than those in the northwest, 519 downgrade of the garnet isograd. The preferred temperature estimate for the regional rocks is therefore $500 \pm 20^{\circ} \mathrm{C}$, shown as a band in Figure $4 \mathrm{~b}$.

521 This estimate assumes that there was no overstepping of the garnet-forming reaction due 522 to kinetic impediments to garnet nucleation and growth. If overstepping was significant, the 523 upper limit could be higher, although there is currently little consensus on the magnitude of 524 overstepping of garnet formation, with estimates ranging from zero (George \& Gaidies, 2016) to 525 tens of degrees (Kelly, Carlson, \& Ketcham, 2013; Spear, Thomas, \& Hallett, 2014). We favour 526 the lower end of the range because of the absence of higher grade isograds within tens of $\mathrm{km}$ of 527 the area shown in Figure 2a (see also Figures 1 and 2 of Pattison, 2013). A dashed line at $540{ }^{\circ} \mathrm{C}$ 528 has therefore been added to Figure $4 \mathrm{~b}$ as an upper limit of the regional temperatures.

Two samples (92-4b and 92-65 in Figure 2 and Table 3) occur outside of the cordierite-in isograd of the aureole $\left(\sim 550{ }^{\circ} \mathrm{C}\right)$, but within about $500 \mathrm{~m}$ of it, and thus likely experienced

531 contact metamorphic temperature that exceeded the regional temperature, but not enough to 532 effect recrystallization. The estimated contact metamorphic temperature for the samples in Table 5333 outside of the cordierite isograd are based on extrapolation of the thermal profile in Figure $4 \mathrm{~b}$.

5355 / ABUNDANCE, MICROTEXTURES AND RAMAN SPECTROSCOPY OF 536 CARBONACEOUS MATERIAL

\section{1 / Abundance and microtextures of carbonaceous material}

Carbonaceous material is present in all lithologies examined from the two aureoles. Figure 5 541 depicts images of whole thin sections from different zones inside the aureoles, meaning upgrade 
542 of the garnet-in isograd at Nelson and upgrade of the cordierite-in isograd at Ballachulish, as 543 well as rocks outside these isograds.

544 Whole rock carbon contents from seven samples from the Nelson aureole in Figure 1b 545 range from 0.04 to $1.22 \mathrm{wt} \%$, corresponding to $0.05-1.5$ volume \% graphite (appendix 1 of 546 Pattison \& Vogl, 2005). Carbonaceous material persists to the highest grades and shows no 547 significant variation in abundance with grade, although rocks from the highest grade appear 548 lighter coloured (Figure 5). In the Ballachulish aureole, Pattison (2006) examined optically 58 549 samples spanning the range of grade in the Ballachulish aureole. Thirteen were selected for whole rock carbon analysis, of which five were chosen for carbon X-ray mapping in order to examine variations in the microscopic distribution and texture of CM (termed graphite in that 552 study) with grade. The $\mathrm{C}$ content varies from 0.35 to $1.02 \mathrm{wt} \%$, corresponding to $0.4-1.2$ volume $553 \%$ graphite. CM persists to the highest grades and shows no significant variation in abundance 554 with grade, except for a possible decrease in the highest grade rocks (Figure 2 of Pattison, 2006), 555 consistent with local 'bleaching' of the rocks as noted at Nelson. Variable abundance of CM in rocks at the same grade was interpreted to reflect primary sedimentological heterogeneity. 557 Thermodynamic calculations suggested that only $0.1-0.3$ volume percent CM (graphitic carbon) 558 was consumed during contact metamorphism (Pattison, 2006).

One of the main differences between the two settings is in the textures of the rocks outside the aureoles and in the most external part of the aureoles. In the Nelson aureole, the lowest grade rocks have a texture reminiscent of black shales observed in subgreenschist facies

562 settings elsewhere. Conversely, in the case of Ballachulish, rocks from outside the aureole texturally look like schists with a clear foliation defined by chlorite and muscovite and CM.

Figure 6 presents representative photomicrographs illustrating microtextures of CM in the

565 rocks outside the aureoles, meaning downgrade of the first development of garnet and staurolite 566 at Nelson and cordierite at Ballachulish. The Nelson rocks exhibit a very fine-grained 567 mineralogy mostly composed of quartz and some phyllosilicates (muscovite, chlorite and 568 biotite). In these rocks, CM is either dispersed in the mineral matrix, or concentrated in diffuse 569 planes within dark beds that may correspond to an original sedimentary structure. Regional rocks 570 from outside the Ballachulish aureole are fine grained as well but systematically exhibit a 571 marked foliation defined by aligned phyllosilicates (muscovite and chlorite) and CM. 
Photomicrographs illustrating the microtexture of rocks within the Nelson aureole are

573 provided in Figures 5 and 6 of Pattison and Vogl (2005) and Figures 2 to 10 of Pattison and

574 Tinkham (2009). Carbonaceous material occurs finely dispersed in the matrix, as fine inclusions

575 in garnet, staurolite and andalusite porphyroblasts, the latter commonly chiastolitic, and in build-

576 ups on the margins of andalusite porphyroblasts. Photomicrographs illustrating the microtexture

577 of rocks within the Ballachulish aureole are provided in Pattison and Harte (1991) and in Figure

5784 of Pattison (2006). Figure 5 of Pattison (2006) shows thin section carbon maps illustrating

579 changes in the distribution and texture of CM going upgrade in the aureole. In regional rocks and

580 in aureole rocks up to zone III (cordierite zone), CM is finely dispersed in the matrix of the rocks

581 and in porphyroblasts of cordierite, where present. CM does not show any demonstrable contact

582 metamorphic-associated textural modification until andalusite develops, where CM accumulates

583 in build-ups on the margins of andalusite porphyroblasts. Overall, at Ballachulish, grains and

584 aggregates of CM in the rock matrix become coarser grained and more widely separated as grade

585 increases. These contact metamorphic-induced textural modifications of CM are superimposed

586 on more pronounced mechanically-induced features, such as segregations along cleavages and

587 crenulations, that formed during regional deformation and garnet zone metamorphism prior to

588 contact metamorphism. As discussed below, these pre-existing characteristics of the CM may

589 have influenced the degree to which it equilibrated in the contact metamorphic event.

590

\section{2 / Raman spectroscopy of carbonaceous material in the Nelson and Ballachulish aureoles}

Raman spectral analysis, including $\mathrm{R} 2$ ratio and $\mathrm{RSCM}$ temperature, together with the petrological temperature estimates, are presented in Tables 2 and 3, respectively, for the Nelson and Ballachulish aureoles. Figure 7 presents representative Raman spectra of CM obtained in the two aureoles. The Raman spectra of CM were collected from different textural settings in the rocks: diffuse $\mathrm{CM}$ in the mineral matrix, $\mathrm{CM}$ in the foliation planes, and $\mathrm{CM}$ inclusions in

598 various porphyroblasts. No significant spectral differences among these populations were 599 observed.

In both aureoles, CM outside of the porphyroblast-in isograds exhibits a $\mathrm{G}$ band as well 601 as the main defect bands D1 and D2, and the spectra are characteristic of disordered graphitic 602 carbon. This graphitic carbon is relatively well ordered as indicated by the relatively low 
603

intensity of both D1 and D2 bands. However, inspection of the second order region reveals an important difference between both settings. In the Nelson area, graphitic carbon did not reach the tridimensional structure of graphite, as the $\mathrm{S} 1$ band at $\sim 2700 \mathrm{~cm}^{-1}$ is still symmetric (top spectrum for Nelson in Figure 7). Conversely, all spectra retrieved from regional rocks outside the Ballachulish aureole exhibit an asymmetric S1 band, revealing that graphitic carbon has started to establish the tridimensional stacking (top spectrum for Ballachulish in Figure 7). Going upgrade in both aureoles, there is a decrease of both D1 and D2 bands up to complete disappearance in the highest grade zones close to the contact with the granitic intrusions (Figure 7). However, a conspicuous difference is that in the Nelson aureole the evolution of the Raman spectra is relatively smooth and progressive, whereas in the Ballachulish aureole the Raman spectra remain relatively constant up to the K-feldspar isograd, and then evolve rapidly to the spectra of perfect graphite. In both aureoles, perfectly crystallized tridimensional graphite is observed in the highest grade samples at the contact with plutonic rocks, as indicated by the absence of D1 and D2 defect bands in the spectra and confirmed by the systematic complete splitting in two bands of the main second order band at $2700 \mathrm{~cm}^{-1}$ (indicative of 3D stacking).

A key observation is that the S1 band is symmetric at Nelson (one single band) and assymetric in Ballachulish (split in two bands) outside of the contact aureoles. This means that $\mathrm{CM}$ is still turbostratic at Nelson (the graphitic planes are twisted and have not reached the $\mathrm{ABAB}$ tridimensionnal stacking of graphite) whereas it has started to reach the tridimensional structure of graphite in the case of Ballachulish. This splitting of the $\mathrm{S} 1$ band is a very sensitive marker for detecting tridimensionnal stacking in graphitic carbon (Lespade et al., 1984). It has been used and discussed for investigating the structure of graphitic carbons in metamorphic rocks (Beyssac, Rouzaud, Goffé, Brunet, \& Chopin, 2002b) and of synthetic graphitic carbons during pyrolysis (Bernard et al., 2010) in combination with Transmitted Electron Microscopy and/or X-ray or electron diffraction techniques. It has also been used to distinguish two kind of graphitic carbon in the same high-P metasomatic rock: turbostratic graphitic carbon deriving from graphitization of organic matter in the host unmetasomatised rock versus hydrothermal graphitic carbon formed by infiltration-driven reduction of carbonates during subduction (Galvez et al., 2013). In CM from metamorphic settings, this splitting of the $\mathrm{S} 1$ band is typically observed for a $\mathrm{R} 2$ ratio of $\sim 0.3$ (Beyssac et al., 2002a) corresponding to temperatures in the range 500$550^{\circ} \mathrm{C}$ (Wopenka \& Pasteris, 1993; Beyssac et al., 2002a). This corresponds to the range of R2 
ratio observed in the rocks outside the Nelson and Ballachulish aureoles. In addition, this suggests that at Nelson the contact metamorphic overprint outside the aureole did not trigger the local tridimensionnal ordering of 'CM' although it was likely not far to do so as this splitting of $\mathrm{S} 1$ rapidly appears within the contact aureole (i.e. above the Grt-in isograd).

Evolution of the R2 ratio in the two aureoles is illustrated in Figure 8 and confirms the qualitative evolution of graphitization described above from the visual inspection of Raman spectra. At Nelson (Figure 8a), R2 is relatively constant outside the porphyroblast-in isograd at a value around 0.25 . Going upgrade in the aureole, $\mathrm{R} 2$ decreases progressively from $\sim 0.25$ to 0.0 , the value of perfect graphite, with no abrupt changes including at the main mineral isograds. Locally some outliers exhibiting higher or lower R2 values are observed, showing that graphitization proceeds with some heterogeneity within the aureole. The standard deviation for the average R2 value in each sample, in the range 0.04-0.07, shows no systematic pattern with distance to the pluton, showing that the within-sample structural heterogeneity of $\mathrm{CM}$ is relatively uniform in all these rocks along the transect. At Ballachulish (Figure 8b), the range in R2 for the regional rocks outside the cordierite-in isograd is similar to that for the lowest grade rocks at Nelson, but slightly more heterogeneous towards lower values (Figure 8 and Tables 2 and 3). It remains relatively unchanged and constant through the aureole until approximately the K-feldspar isograd, within $200 \mathrm{~m}$ of the igneous contact, where it decreases abruptly to the null value of graphite. As at Nelson, the standard deviation for R2 values of individual samples is more or less constant as a function of distance to the pluton, in the range 0.04-0.07, showing that the structural heterogeneity of $\mathrm{CM}$ is relatively uniform in all these rocks.

\section{6 / DELAYED RECRYSTALLIZATION OF PREVIOUSLY METAMORPHOSED CARBONACEOUS MATERIAL AT BALLACHULISH}

Several studies have compared graphitization patterns between contact and regional metamorphism. Earlier studies used X ray diffraction to investigate the structure of $\mathrm{CM}$ extracted from rocks and concluded that there might be a slight delay of graphitization in contact aureoles when compared to rocks of equivalent grade in a regional metamorphic gradient (Grew, 1974; Okuyama-Kusunose \& Itaya, 1987), or no real difference except in the outer low grade parts of contact aureoles (Wada et al., 1994). Alternatively, more recent studies used Raman 
665 666

667

668

669

670

671

672

673

674

675

676

677

678

679

680

681

682

683

684

685

686

687

688

689

690

691

692

693

694

695

microspectroscopy to quantify in situ the CM degree of graphitization and were focused on calculating RSCM temperatures (Aoya et al., 2010; Hilchie \& Jamieson, 2014; Delchini, Lahfid, Plunder, \& Michard, 2016). Based on RSCM temperatures, they all concluded that graphitization proceeds to the same degree for a given metamorphic grade in both contact and regional metamorphic settings. In the studies by Aoya et al. (2010), Hilchie \& Jamieson (2014) and Delchini et al. (2016), contact metamorphism was superposed on rocks that had already experienced greenschist facies regional metamorphism with temperature estimated in the range $300-400^{\circ} \mathrm{C}$. Reasons for different conclusions among the early $\mathrm{X}$ ray diffraction based studies and later studies based on Raman microspectroscopy are unclear and it might be a consequence of an analytical discrepancy as $\mathrm{X}$ ray diffraction is a bulk technique whereas Raman microspectroscopy only probes a few $\mu \mathrm{m}^{3}$. It can be a consequence of sample preparation as well as $\mathrm{X}$ ray diffraction requires mechanical and chemical extraction of $\mathrm{CM}$ from the rocks which may alter the fragile structure of highly ordered graphitic carbon like those typically observed in contact aureoles. Regardless of the characterization technique, the graphitization pattern in the aureoles is systematically progressive and continuous with increasing grade. This situation corresponds to the pattern of graphitization observed in the Nelson aureole, where the intrusion was emplaced in regional rocks that were essentially unmetamorphosed (subgreenschist facies; see section 4.1).

Two contrasted patterns are observed for the progress of graphitization with increasing contact metamorphism in the Nelson and Ballachulisch aureoles. Nelson aureole exhibits a progressive and continuous steady crystallization of $\mathrm{CM}$ following the progressive $\mathrm{T}$ increase towards the granitic intrusion with no noticeable break at the main mineral isograds. Some local heterogenity is observed, the causes of which are unknown. Conversely, the pattern of graphitization at Ballachulish is different. Based on Raman spectroscopy proxies (R2 ratio, shape of the $\mathrm{S} 1$ band), $\mathrm{CM}$ structure seems to remain relatively uniform throughout the transect up to $\sim 200 \mathrm{~m}$ from the contact with the intrusion, at approximately the K-feldspar isograd; at that point, there is an abrupt increase in graphitization. In both settings, perfect graphite with tridimensionnal stacking is observed in the highest grade rocks close to the contact with the intrusion.

Inspection of the rock textures (Figure 5) and microtextures (Figure 6) reveals a marked difference for the rocks outside the aureole although the $\mathrm{R} 2$ ratio for $\mathrm{CM}$ is nearly the same in 
both settings: the Nelson rocks have a textural habit similar to low grade metamorphic rocks whereas the Ballachulish rock has the habit of a micashist with a well marked foliation. Nonetheless, rocks sampled downgrade of the porphyroblast-in isograd at Nelson were also submitted to the thermal effects of contact metamorphism as recorded by RSCM thermometry. This result is consistent with the regional isograd pattern and with the random texture of biotite in the low grade rocks which is suggestive of relatively static contact metamorphism (see discussion in section 4.1.4).

At Ballachulish, CM had already reached locally the tridimensional ordering of graphite before the intrusion and formation of the contact aureole. This pre-transformation of CM is likely responsible for the sluggish recrystallization and delayed graphitization observed in this aureole. Tridimensional ordering of graphitic carbon means that the graphitic planes are wide enough to develop strong long range Van Der Waals interactions over large areas among them to get closer and have a $\mathrm{d}_{002}$ spacing tending towards 3.35 angstroms as detected by $\mathrm{X}$ ray diffraction in perfect graphite. However, this 'CM starting material' was still partially disordered as attested by the presence of D1 and D2 bands in the first-order region as well as by the incomplete splitting of the S1 band in the second order region. In reality, at the nanoscale such CM was likely microtexturally and structurally heterogeneous, containing some nucleation zones for the development and propagation of tridimensional ordering as observed in other metamorphic settings by high-resolution Transmission Electron Microscopy (Buseck \& Huang, 1985; Beyssac et al., 2002b). Such heterogeneous nucleation and propagation of graphitization at the nanoscale has been reproduced and observed in synthetic CM retrieved from high-P and high-temperature experiments (Beyssac et al., 2003a).

It appears that further graphitization of such pre-textured CM required a significant temperature overstepping compared to other settings where ' $\mathrm{CM}$ starting material' was still turbostratic (Nelson, this study; Aoya et al., 2010; Hilchie \& Jamieson, 2014; Delchini et al., 2016). The final stage of graphitization mostly consists in polymerization (extending the graphitic planes) and tridimensional ordering of the graphitic planes. At Ballachulish, this final graphitization stage may have required additional energy to re-organize the pre-existing strong, but imperfect, structure compared to the steady graphitization observed at Nelson and other aureoles. Interestingly, graphitization of this CM at Ballachulish starts at the K-feldspar isograd which corresponds to the breakdown of muscovite and to a major fluid release which may have 
727 had a role to trigger graphitization at Ballachulish by possibly lowering some of the kinetic

728 barriers. However, no significant break in graphitization is observed at the chlorite-out isograd 729 which corresponds to the biggest fluid release (56\% of water released vs. 20\% at Ms-out; see 730 Figure 8 of Pattison, 2006). We do not have a clear mechanism at this stage to explain this 731 delayed graphitization which could alternatively be the consequence of an arrhenius-type thermal 732 threshold; further work including investigations in other natural settings or experimental work is 733 needed to pursue these ideas.

\section{7 / IMPLICATIONS FOR RSCM THERMOMETRY}

\section{1 / RSCM temperatures in the Ballachulish and Nelson aureoles}

R2 values can be used to calculate peak metamorphic temperature with equations calibrated using samples affected by regional metamorphism (Beyssac et al., 2002a; Aoya et al., 2010 their 'regional' calibration) or contact metamorphism (Aoya et al. 2010 - their 'contact' calibration). The temperature results for Nelson and Ballachulish, in combination with temperature estimates retrieved from petrology (see above), are given in Tables 2 and 3, and shown on Figure 4a,b respectively.

For initial analysis, we discuss temperature calculated with the calibration by Beyssac et al. (2002a); comparison with the calibrations by Aoya et al. (2010) follows. In both aureoles, RSCM temperature for the remote samples collected far from the intrusions are quite similar at about $525-535^{\circ} \mathrm{C}$ for Nelson and are slightly higher but more dispersed for Ballachulish in the range $520-550^{\circ} \mathrm{C}$. As discussed above, these temperatures likely reflect contact metamorphism associated with the Nelson intrusion while they represent pre-intrusion regional metamorphism at Ballachulish. At the other extreme, perfect graphite is observed (no D1 defect band, R2=0.0, splitting of the S1 band) indicating temperature higher than $640^{\circ} \mathrm{C}$. Due to the linear character of

753 the relationship between the R2 parameter and temperature, the evolution of temperature in 754 between these end-members follows the same pattern described above for the evolution of R2 in 755 both aureoles: progressive within the transect for Nelson, and no change until an abrupt increase 756 in the innermost zones at Ballachulish. This situation contrasts with the petrological constraints 757 that show a progressive increase in temperature as the contact is approached in both aureoles. 
7.2 / Comparison with other areas and RSCM thermometry in contact aureoles: testing calibrations

761

762

763

764

765

766

767

768

769

770

771

772

773

774

775

776

777

778

779

780

781

782

783

784

785

786

787

788

RSCM thermometry was initially calibrated by using petrological data from samples affected by a single regional metamorphic event (Beyssac et al., 2002a, here B02) with an estimated uncertainty of $\pm 50^{\circ} \mathrm{C}$. This initial calibration was a linear fit between the $\mathrm{R} 2$ ratio and petrologic temperature and likely slightly underestimated temperature at values higher than $600-620^{\circ} \mathrm{C}$ (Negro, Beyssac, Goffé, Saddiqi, \& Bouybaouene, 2006); a quadratic equation was not chosen by Beyssac et al. (2002a) because of a lack of data at such high T. Aoya et al. (2010) modified this initial calibration for regional metamorphism (referred to here as A10r) by using a quadratic equation to fit the dataset from Beyssac et al. (2002a) but added no new data. For contact metamorphism, Aoya et al. (2010) developed a calibration based on the study of contact aureoles in Japan for which temperature is estimated from the combination of various thermometers for anchor points and interpolation for samples between based on thermal modelling (referred to here as A10c); an approach similar in principle to ours for Ballachulish and Nelson. Figure 4a,b show that the RSCM temperatures retrieved by the two calibrations A10r and A10c are only slightly different than those obtained with the B02, with systematically greater difference between B02/A10r versus A10c. In Figure 9, we compare the results of the three calibrations with temperatures from petrology for the Nelson aureole. We note that (i) the B02 calibration is relatively close to the A10r calibration for the samples outside the contact aureole and that the A10c calibration is higher, (ii) the A10r temperatures generally fall in the middle range of B02 and A10c within the contact aureole and (iii) there is a generally better agreement of the B02 calibration with the petrological constraints except for the highest temperature points. At Ballachulish, the B02 calibration is very close to the A10r calibration for the samples outside the contact aureole while the A10c is then higher by $\sim 20^{\circ} \mathrm{C}$, but we do not make a comparison within the aureole as RSCM thermometry does not appear to be be applicable there as discussed above.

The A10r calibration generally yields higher temperature estimates at temperatures above $600^{\circ} \mathrm{C}$ due to its quadratic nature but the constraints in this temperature range in the $\mathrm{B} 02$ dataset used by A10r are limited. The differences between B02 and A10c likely come from the 
789

790

791

792

793

794

795

796

797

798

799

800

801

802

803

804

temperature estimates by petrology used as reference for the calibration (all petrological estimates for B02 and a combination of petrological estimates and thermal modelling for A10c).

One may ask the reason for using different calibrations between contact and regional metamorphism as all recent studies showed no kinetic effect on graphitization on such timescales. There is actually an excellent agreement between RSCM estimates whatever the calibration (B02, A10r or A10c) and petrological data and/or temperature retrieved from thermal modelling (Aoya et al., 2010; Hilchie \& Jamieson, 2014; Delchini et al., 2016). This is in agreement with a recent kinetic modelling of graphitization which shows that this transformation proceeds rapidly in most metamorphic settings (Nakamura et al., 2017). In very short timescale heating events (100-500 years), such as heating induced by a sill intrusion, graphitization may be limited by the duration of the thermal event (Mori, Mori, Wallis, Westaway, \& Annen, 2016) but this is different than the timescale for contact metamorphism developed in contact aureoles due to the emplacement of igneous intrusions on the scale of $\mathrm{km}$, which is typically 100's of thousands of years for rocks raised to $\mathrm{T}>500^{\circ} \mathrm{C}$, such as Nelson and Ballachulish (see references above). This point is further supported by a plot of RSCM temperature data in contact aureole versus reference temperature estimates from the same source paper (this study; Aoya et al., 2010; Hilchie \& Jamieson, 2014; Delchini et al.,2016) presented in Figure 10. Reference temperature is an independent petrological estimate of temperature, except for the Halifax aureole in Nova Scorta, where it is quantified from thermal modelling with input from conventional petrology and RSCM thermometry (Hilchie \& Jamieson, 2014). Apart from Ballachulish, the data mainly fall around the $1: 1$ line within an envelop of $\pm 25^{\circ} \mathrm{C}$ except for a few outliers. The case of Ballachulish is different and likely due to the complex polymetamorphic history of these rocks as discussed above.

\section{8 / CONCLUSION: SOME IMPLICATIONS FOR RSCM THERMOMETRY}

The graphitization pattern and calculated RSCM temperatures were examined in two wellcharacterised contact aureoles with contrasting metamorphic histories. In the case of Nelson where contact metamorphism overprints essentially unmetamorphosed rocks, the graphitization pattern is controlled by the temperature increase in the contact aureole. The RSCM thermometry nicely records the thermal signature of the contact metamorphism and is in good agreement with petrological data. Interestingly, RSCM thermometry showed that rocks outside the contact 
820

821

822

823

824

825

826

827

828

829

830

831

832

833

834

835

836

837

838

839

840

841 842 about $500^{\circ} \mathrm{C}$.

843

844

845

846

847

848

849

aureole, as defined by the porphyroblast-in isograd, were likely affected by the same contact metamorphic imprint even though there is little mineralogical evidence. A similar observation was done by Hilchie and Jamieson (2014) which opens new avenues for tracking the thermal overprint of intrusions with RSCM thermometry in rocks outside of the porphyroblast-bearing zones where mineralogical changes are more subtle and harder to quantify petrologically.

The case of Ballachulish is different as the intrusion was emplaced into rocks that had already been affected by high-grade garnet zone (lower amphibolite facies) metamorphism at $\mathrm{T}>500^{\circ} \mathrm{C}$. We have shown that this regional metamorphism transformed the CM into a highly ordered material at the threshold of tridimensional ordering of graphite prior to contact metamorphism. Recrystallization of CM and graphitization in the Ballachulish aureole was delayed likely due to the pre-texturation of $\mathrm{CM}$ during regional metamorphism with the result that the RSCM thermometry underestimates peak temperature in the aureole. Such a delay in graphitization has not been observed in the case of two successive regional metamorphic events even if the first one reached high-grade conditions : this was shown in the central part of the southern Alps of New Zealand (Beyssac, Cox, Vry, \& Herman, 2016) or in some part of the European Alps (Wiederkehr, Bousquet, Ziemann, Berger, \& Schmid, 2011). Note that in these settings, the successive regional metamorphisms are large-scale mostly due to burial related to subduction and/or collision. This makes the situation completely different from Ballachulish where a thermal perturbation due to a hot intrusion locally overprints a pre-existing regional metamorphism. In any case, the Ballachulish case-study shows that RSCM thermometry needs to be applied with caution in polymetamorphic settings involving an early event that exceeded

\section{ACKNOWLEDGEMENTS}

OB acknowledges funding from Sorbonne Universités (PERSU program) and the City of Paris (Emergence Program). DP acknowledges NSERC Discovery Grant 037233. We thank L.J. Hilchie and an anonymous reviewer for thorough and constructive reviews and Doug Robinson for editorial handling. 


\section{REFERENCES}

Archibald, D.A., Glover, J.K., Price, R.A., Carmichael, D.M., \& Farrar, E. (1983). Geochronology and tectonic implications of magmatism and metamorphism, Southern Kootenay Arc and neighbouring regions, southeastern British Columbia, Part I: Jurassic to Mid-Cretaceous; Canadian Journal of Earth Sciences, 20, 1891-1913.

Aoya, M., Kouketsu, Y., Endo, S., Shimizu, H., Mizukami, T., Nakamura, D., \& Wallis, S. (2010). Extending the applicability of the Raman carbonaceous-material geothermometer using data from contact metamorphic rocks. Journal of Metamorphic Geology, 28, 895-914.

Bernard, S., Beyssac, O., Benzerara, K., Findling, N., Tzvetkov, G., \& Brown, Jr., G.E. (2010). XANES, Raman and XRD signatures of anthracene-based cokes and saccharose-based chars submitted to high temperature pyrolysis, Carbon, 48, 2506-2516.

Beyssac, O., Goffé, B., Chopin, C., \& Rouzaud, J.N. (2002a). Raman spectra of carbonaceous material in metasediments: a new geothermometer. Journal of Metamorphic Geology, 20, 859-871.

Beyssac, O., Rouzaud, J.N., Goffé, B., Brunet, F. \& Chopin, C. (2002b) Graphitization in a highpressure, low-temperature metamorphic gradient: a Raman microspectroscopy and HRTEM study. Contributions to Mineral Petrology, 143, 19-31.

Beyssac, O., Brunet, F., Petitet, J.P., Goffé, B., \& Rouzaud, J.N. (2003a). Experimental study of the microtextural and structural transformations of carbonaceous materials under pressure and temperature. European Journal of Mineralogy, 15, 937-951.

Beyssac, O., Goffé, B., Petitet, J.P., Froigneux, E., Moreau, M., \& Rouzaud, J.N. (2003b). On the characterization of disordered and heterogeneous carbonaceous materials by Raman spectroscopy. Spectrochimica Acta Part A, 59, 2267-2276.

Beyssac, O., Bollinger, L., Avouac, J.P., \& Goffé, B. (2004). Thermal metamorphism in the lesser Himalaya of Nepal determined from Raman spectroscopy of carbonaceous material. Earth and Planetary Science Letters, 225, 233-241.

Beyssac, O., \& Lazzeri, M. (2012). Application of Raman spectroscopy to the study of graphitic carbons in the Earth Sciences. In: Dubessy, J., Caumon, M.-C., \& Rull, F. (Eds) Applications of Raman Spectroscopy to Earth Sciences and Cultural Heritage. EMU Notes in Mineralogy, $12,415-454$.

Beyssac, O., Cox, S.C., Vry, J.K., \& Herman, F. (2016). Peak metamorphic temperature and thermal history of the Southern Alps (New Zealand). Tectonophysics, 676, 229-249.

Buntebarth, G. (1991). Thermal models of cooling. In: G. Voll, J. Töpel, D.R.M. Pattison and F. Seifert, F. (Eds.) Equilibrium and kinetics in contact metamorphism: The Ballachulish Igneous Complex and its thermal aureole. Springer Verlag: Heidelberg, 379-404.

Buseck, P.R., \& Beyssac, O. (2014). From organic matter to graphite : graphitization. Elements $10(6), 421-426$.

Buseck, P.R., \& Huang, B-J. (1985). Conversion of carbonaceous material to graphite during metamorphism. Geochimica et Cosmochimica Acta, 49, 2003-2016.

Busemann, H., Alexander, M. O'D., \& Nittler, L. R. (2007). Characterization of insoluble organic matter in primitive meteorites by microRaman spectroscopy. Meteoritics \& Planetary Science, 42, 1387-1416. 
Coggon, R., \& Holland, T.J.B. (2002). Mixing properties of phengitic micas and revised garnetphengite thermobarometers. Journal of Metamorphic Geology, 20, 683-696.

Connolly, J.A.D., \& Cesare, B. (1993). C-O-H-S fluid compositions and oxygen fugacity in graphitic metapelites. Journal of Metamorphic Geology, 11, 379-388.

Cook, F. A., Green, A. G., Simony, P. S., Price, R. A., Parrish, R. R., Milkereit, B., Gordy, P. L., Brown, R. L., Coffin, K. C., \& Patenaude, C. (1988). Lithoprobe seismic reflection structure of the southeastern Canadian Cordillera: Initial results. Tectonics, 7, 157-180.

de Capitani, C., \& Brown, T.H. (1987). The computation of chemical equilibria in complex systems containing non-ideal solutions. Geochimica et Cosmochimica Acta, 51, 2639-2652.

de Capitani, C., \& Petrakakis, K. (2010). The computation of equilibrium assemblage diagrams with Theriak/Domino software. American Mineralogist, 95, 1006-1016.

Delchini, S., Lahfid, A., Plunder, A., \& Michard A. (2016). Applicability of the RSCM geothermometry approach in a complex tectono-metamorphic context (Variscan orogen, Morocco). Lithos, 256-257,1-12.

Ferry, J.M. (1996). Prograde and retrograde fluid flow during contact metamorphism of siliceous carbonate rocks from the Ballachulish aureole, Scotland. Contributions to Mineralogy and Petrology, 124, 235-254.

Fraser, G.L., Pattison, D.R.M., \& Heaman, L.M. (2004). Age of the Ballachulish and Glencoe Igneous Complexes (Scottish Highlands), and paragenesis of zircon, monazite and baddeleyite in the Ballachulish Aureole. Journal of the Geological Society of London, 161, 447-462.

Galvez, M.E., Beyssac, O., Martinez, I., Benzerara, K., Chaduteau, C., Malvoisin, B., \& Malavieille, J. (2013). Graphite formation by carbonate reduction during subduction. Nature Geoscience, 6 (6), 473-477.

Galy, V., Beyssac, O., France-Lanord, C., \& Eglinton, T. (2008). Selective recycling of graphite during Himalayan erosion: a geological stabilisation of C in the crust. Science, 322, 943-945.

George, F.R., \& Gaidies, F. (2017). Characterisation of a garnet population from the Sikkim Himalaya: insights into the rates and mechanisms of porphyroblast crystallization. Contributions to Mineralogy and Petrology, 172, DOI 10.1007/s00410-017-1372-y.

Ghosh, D.K. (1995). U-Pb geochronology of Jurassic to early Tertiary granitic intrusives from the Nelson-Castlegar area, southeastern British Columbia, Canada. Canadian Journal of Earth Sciences, 32, 1668-1680.

Grew, E.S. (1974). Carbonaceous material in some metamorphic rocks of New England and other areas. The Journal of Geology, 82, 50-73.

Harte, B., Pattison, D.R.M., Heuss-Assbichler, S., Hoernes, S., Masch, L., \& Strong, D.F. (1991). Evidence of fluid phase behaviour and controls in the intrusive complex and its aureole. In: G. Voll, J. Töpel, D.R.M. Pattison and F. Seifert, F. (Eds.) Equilibrium and kinetics in contact metamorphism: The Ballachulish Igneous Complex and its thermal aureole. Springer Verlag: Heidelberg, 405-422.

Hilchie, L.J., \& Jamieson, R.A. (2014). Graphite thermometry in a low-pressure contact aureole, Halifax, Nova Scotia. Lithos, 208-209, 21-33.

Holland, T.J.B. \& Powell, R. (1998). An internally consistent thermodynamic data set for phases of petrological interest. Journal of Metamorphic Geology, 16, 309-344.

Holland, T.J.B., \& Powell, R. (2003). Activity-composition relations for phases in petrological calculations: an asymmetric multicomponent formulation. Contributions to Mineralogy and Petrology, 145, 492-501. 
Kelly, E.D., Carlson, W.D. \& Ketcham, R.A. (2013). Magnitudes of departure from equilibrium during regional metamorphism of porphyroblastic rocks. Journal of Metamorphic Geology, 31, 981-1002.

Kretz, R. (1983). Symbols for rock-forming minerals. American Mineralogist, 68, 277-279.

Lespade, P., Marchand, A., Couzi, M., \& Cruege, F. (1984). Characterization of carbon materials with Raman microspectrometry. Carbon, 22, 375-385.

Little, H.W. (1960). Nelson Map-area, West-half, British Columbia. Geological Survey of Canada, Memoir 308, 205 pages.

Morgan, A.L. (2016). Metamorphism of the Rossland Group metabasalts and metapelites, southeastern British Columbia. Unpublished BSc thesis, University of Calgary, $131 \mathrm{pp}$.

Mori, H., Mori, N., Wallis, S., Westaway, R., \& Annen, C. (2016). The importance of heating duration for Raman CM thermometry: evidence from contact metamorphism around the Great Whin Sill intrusion, UK. Journal of Metamorphic Geology, 35, 165-180.

Nakamura, Y., Yoshino, T., \& Satish-Kumar, M. (2017). An experimental kinetic study on the structural evolution of natural carbonaceous material to graphite. American Mineralogist, 102, 135-148.

Negro, F., Beyssac, O., Goffé, B., Saddiqi, O., \& Bouybaouene, M. (2006). Thermal structure of the Alboran Domain in the Rif (northern Morocco) and the Western Betics (southern Spain). Constraints from Raman Spectroscopy of Carbonaceous Material. Journal of Metamorphic Geology, 24, 309-327.

Okuyama-Kusunose, Y., \& Itaya, T. (1987). Metamorphism of carbonaceous material in the Tono contact aureole, Kitakami Mountains, Japan. Journal of Metamorphic Geology, 5, 121139.

Parrish, R.R. (1992). U-Pb ages of Jurassic-Eocene plutonic rocks in the vicinity of the Valhalla Complex, southeastern British Columbia. In: Radiogenic age and isotopic studies: Report 5. Geological Survey Canada Paper 91-2, 115-134.

Pattison, D.R.M. (1989). P-T conditions and the influence of graphite on pelitic phase relations in the Ballachulish aureole, Scotland. Journal of Petrology, 30, 1219-1244.

Pattison, D.R.M. (1992). Stability of andalusite and sillimanite and the $\mathrm{Al}_{2} \mathrm{SiO}_{5}$ triple point: Constraints from the Ballachulish aureole, Scotland. Journal of Geology, 100, 423-446.

Pattison, D.R.M. (2013). Regional metamorphism in the Ballachulish area, SW Highlands, Scotland: new perspectives on a famous old debate, with regional implications. Journal of the Geological Society of London, 170, 417-434.

Pattison, D., \& Harte, B. (1985). A petrogenetic grid for pelites in the Ballachulish aureole and other Scottish thermal aureoles. Journal of the Geological Society of London, 142, 7-28.

Pattison, D.R.M., \& Harte, B. (1991). Petrography and mineral chemistry of pelites. In: G. Voll, J. Töpel, D.R.M. Pattison and F. Seifert, F. (Eds.) Equilibrium and kinetics in contact metamorphism: The Ballachulish Igneous Complex and its thermal aureole. Springer Verlag: Heidelberg, 135-180.

Pattison, D.R.M., \& Harte, B. (1997). The geology and evolution of the Ballachulish igneous Complex and Aureole. Scottish Journal of Geology, 33, 1-29.

Pattison, D.R.M., \& Harte, B. (2001). The Ballachulish Igneous Complex and Aureole: a field guide. Edinburgh Geological Society, Edinburgh, Scotland, 148 pp.

Pattison, D.R.M., \& Vogl, J.J (2005). Contrasting sequences of metapelitic mineral-assemblages in the aureole of the tilted Nelson Batholith, British Columbia: implications for phase 
equilibria and pressure determination in andalusite-sillimanite type settings. Canadian Mineralogist, 43, 51-88.

Pattison, D.R.M., \& Voll, G. (1991). Regional geology of the Ballachulish area. In: G. Voll, J. Töpel, D.R.M. Pattison and F. Seifert, F. (Eds.) Equilibrium and kinetics in contact metamorphism: The Ballachulish Igneous Complex and its thermal aureole. Springer Verlag: Heidelberg, 19-38.

Pattison, D.R.M., Spear, F.S., BeBuhr, C.L., Cheney, J.T., \& Guidotti, C.V. (2002). Thermodynamic modelling of the reaction Muscovite + Cordierite $=\mathrm{Al}_{2} \mathrm{SiO}_{5}+$ Biotite + Quartz $+\mathrm{H}_{2} \mathrm{O}$ : constraints from natural assemblages and implications for the metapelitic petrogenetic grid. Journal of Metamorphic Geology, 20, 99-118.

Pattison, D.R.M., \& DeBuhr, C.L. (2015). Petrology of metapelites in the Bugaboo aureole, British Columbia, Canada. Journal of Metamorphic Geology, 33, 437-462.

Pattison, D.R.M., \& Tinkham, D.T. (2009). Interplay between equilibrium and kinetics in prograde metamorphism of pelites: an example from the Nelson aureole, British Columbia. Journal of Metamorphic Geology, 27, 249-279.

Pattison, D.R.M. (2006). The fate of graphite in prograde metamorphism of pelites: an example from the Ballachulish aureole, Scotland. Lithos, 88, 85-99.

Pattison, D.R.M., \& Tracy, R.J. (1991). Phase equilibria and thermobarometry of metapelites. In: Contact metamorphism (ed. Kerrick, D.M.), Mineralogical Society of America Reviews in Mineralogy, 26, 105-206.

Pattison, D.R.M., de Capitani, C., \& Gaidies, F. (2011). Petrologic consequences of variations in metamorphic reaction affinity. Journal of Metamorphic Geology, 29, 953-977

Pattison, D.R.M., \& Harte, B. (1991) Petrography and mineral chemistry of pelites. In: Voll, G., Topel, J., Pattison, D.R.M. \& Seifert, F. (eds.) Equilibrium and kinetics in contact metamorphism: The Ballachulish Igneous Complex and its aureole. Springer Verlag: Heidelberg, 135-180.

Powell, W.G., \& Ghent, E.D. (1996). Low-pressure metamorphism of the mafic volcanic rocks of the Rossland Group, southeastern British Columbia. Canadian Journal of Earth Sciences 33, 1402-1409.

Sevigny, J.H., \& Parrish, R.R. (1993). Age and origin of Late Jurassic and Paleocene granitoids, Nelson Batholith, southern British Columbia. Canadian Journal of Earth Sciences, 30, $2305-$ 2314.

Spear, F.S., Thomas, J.B., \& Hallett, B.W. (2014). Overstepping the garnet isograd: a comparison of QuiG barometry and thermodynamic modelling. Contributions to Mineralogy and Petrology, 168, https://doi.org/10.1007/s00410-014-1059-6.

Starr, P.G. (2017). Sub-greenschist to lower amphibolite facies metamorphisk of basalts: Examples from Flin Flon, Manitoba and Rossland, British Columbia. Unpublished PhD thesis, University of Calgary, $495 \mathrm{p}$.

Tinkham, D.K., Zuluaga, C.A., \& Stowell, H.H. (2001). Metapelite phase equilibria modelling in MnNCKFMASH: The effect of variable $\mathrm{Al}_{2} \mathrm{O}_{3}$ and $\mathrm{MgO} /(\mathrm{MgO}+\mathrm{FeO})$ on mineral stability. Mineralogical Society of America: Geological Materials Research, 3, 1-42.

Tinkham, D.K. \& Ghent, E.D. (2005). Estimating P-T conditions of garnet growth with isochemical phase diagram sections and the problem of effective bulk-composition, Canadian Mineralogist, 43, 35-50. 
1028

1029

1030

1031

1032

1033

1034

1035

1036

1037

1038

1039

1040

1041

1042

1043

1044

1045

1046

1047

1048

1049

1050

1051

1052

1053

1054

1055

1056

1057

1058

1059

1060

1061

1062

1063

1064

1065

1066

1067

1068

1069

1070

Tomkins, H.S., \& Pattison, D.R.M. (2007). Accessory phase petrogenesis in relation to major phase assemblages in pelites from the Nelson contact aureole, southern British Columbia. Journal of Metamorphic Geology, 25, 401-421.

Vogl, J.J., \& Simony, P.S. (1992). The southern tail of the Nelson Batholith, southeast British Columbia: structure and emplacement. Geological Survey of Canada Paper, 92-1A, 71-76.

Voll, G., Töpel, J., Pattison, D.R.M., \& Seifert, F. (Eds.) (1991). Equilibrium and kinetics in contact metamorphism: The Ballachulish Igneous Complex and its aureole. Springer Verlag: Heidelberg, $484 \mathrm{p}$.

Wada, H., Tomita, T., Matsuura, K., Iuchi, K., Ito, M., \& Morikiyo, T. (1994). Graphitization of carbonaceous matter during metamorphism with reference to carbonate and pelitic rocks of contact and regional metamorphisms, Japan. Contributions to Mineralogy and Petrology, $118,217-228$.

Weiss, S., \& Troll, G. (1989). The Ballachulish Igneous Complex, Scotland: Petrography, mineral chemistry and order of crystallisation in the monzodiorite-quartz diorite suite and in the granite. Journal of Petrology, 30, 1069-1116.

Weiss, S., \& Troll, G. (1991). Thermal conditions and crystallisation sequence in the Ballachulish Complex. In: G Voll, J Töpel, D.R.M. Pattison and F. Seifert, F. (Eds.) Equilibrium and kinetics in contact metamorphism: The Ballachulish Igneous Complex and its thermal aureole. Springer Verlag: Heidelberg, 67-98.

White, R.W., Pomroy, N.E., \& Powell, R. (2005). An in-situ metatexite-diatexite transition in upper amphibolite facies rocks from Broken Hill, Australia. Journal of Metamorphic Geology, 23, 579-602.

White, R.W., Powell, R. \& Holland T.J.B. (2007) Progress relating to calculation of partial melting equilibria for metapelites. Journal of Metamorphic Geology, 25, 511-527.

White, R.W., Powell, R., Holland, T.J.B., Johnson, T.E., \& Green, C.R. (2014a). New mineral activity-composition relations for thermodynamic calculations in metapelitic systems. Journal of Metamorphic Geology, 32, 261-286.

White, R.W., Powell, R., \& Johnson, T.E. (2014b). The effect of Mn on mineral stability in metapelites revisited: new a-x relations for manganese-bearing minerals. Journal of Metamorphic Geology, 32, 809-828.

Wiederkehr, M., Bousquet, R., Ziemann, M. A., Berger, A., \& Schmid, S.M. (2011). 3-D assessment of peak-metamorphic conditions by Raman spectroscopy of carbonaceous material: an example from the margin of the Lepontine dome (Swiss Central Alps). International Journal of Earth Sciences, 100, 1029-1063.

Wopenka, B., \& Pasteris, J.D. (1993). Structural characterization of kerogens to granulite-facies graphite: applicability of Raman microprobe spectroscopy. American Mineralogist, 78, 533557.

\section{TABLE CAPTIONS}

Table 1. Whole rock compositions used for thermodynamic modelling.

Table 2. Summary of data for the Nelson aureole. Refer to Figures 1b,c for sample locations. See text for discussion of mineral assemblages, uncertainties on distance, and 
petrological temperature estimates and uncertainties. $\mathrm{n}$ - number of Raman spectra. R2 - Raman R2 ratio. T(B02), T(A10r), T(A10c) - RSCM temperatures from calibrations of Beyssac, Goffé, Chopin, \& Rouzaud (2002a), Aoya et al. (2010) with A10r for regional and A10c for contact. SDV - standard deviation. SE - standard error (Standard error is the standard deviation divided by $\sqrt{ } \mathrm{N}$ ). See text for details.

Table 3. Summary of data for the Ballachulish aureole. Refer to Figures 2a,b for sample locations. $\mathrm{C}$ - contact. $\mathrm{R}$ - regional. See text for discussion of mineral assemblages, uncertainties on distance, and petrological temperature estimates and uncertainties. $\mathrm{n}$ number of Raman spectra. R2 - Raman R2 ratio. T(B02), T(A10r), T(A10c) - RSCM temperatures from calibrations of Beyssac, Goffé, Chopin, \& Rouzaud (2002a), Aoya et al. (2010) with A10r for regional and A10c for contact. SDV - standard deviation. SE standard error (Standard error is the standard deviation divided by $\sqrt{ } \mathrm{N}$ ). See text for details.

\section{FIGURE CAPTIONS}

Figure 1 (a) Regional map of the Nelson batholith and aureole, adapted from Pattison and Vogl (2005) and Moynihan \& Pattison (2013). Dashed lines separate mineral assemblage domains of different pressure, i.e., they are not isograds (see Pattison \& Vogl, 2005, for details). Metamorphic zones involving staurolite and kyanite are part of a regional Barrovian metamorphic culmination that occurs east of the major GallagherMidge Creek fault zone, and which is unrelated to the metamorphism in the study area. (b) Isograds and sample locations (Table 2) from the main study area, adapted from Pattison and Tinkham (2009). Isograds marking the first appearance of index minerals are shown in long dashed lines and those showing the disappearance of index minerals are shown in short dashed lines. The grey solid line is the line used for measuring 
distances of samples from the contact (see text for discussion). (c) Location of samples from south of the main study area.

1100

1101

1102

1104

1105

1106

1107

1108

1109

1110

1111

1112

1113

1114

1115

1116

1117

1118

1119

1120

Figure 2. (a) Geology of the Ballachulish area, modified from Figure 7 of Pattison and Harte (2001), itself based on Weiss and Troll (1989) and Pattison and Harte (1997). The grey solid line is the line of section, approximately normal to the igneous contact, into which sample distances were projected (see text). (b) Metamorphic zones, isograds and sample locations (Table 3) in the area of interest. The grey solid line is the line of section, approximately normal to the igneous contact, into which sample distances were projected (see text).

Figure 3. (a) Thermodynamically calculated phase diagram for the average carbonaceous argillite (Ymir argillite) from the Nelson aureole (composition listed in Table 1, where aluminum index, A', is defined). See text for details of phase diagram calculation. Solid isobaric line and two identified reaction intervals discussed are discussed in text. Andalusite-sillimanite boundary from Pattison (1992). (b) Thermodynamically calculated phase diagram for the average carbonaceous slate (Ballachulish Slate) from the Nelson aureole (composition listed in Table 1). Solid isobaric line and two identified reaction intervals discussed are discussed in text.

Figure 4 (a) Temperature estimates vs. distance from contact in the Nelson aureole, based on data in Table 2. Sample locations and isograd locations from Figs. 1b,c. Uncertainities on temperature estimates from petrology: $\pm 20{ }^{\circ} \mathrm{C}$ (see text for discussion). Uncertainities on temperature estimates from graphite thermometry: $\pm 50^{\circ} \mathrm{C}$ (see text for discussion). (b) Temperature estimates vs. distance from contact in the Ballachulish aureole, based on data in Table 3. Sample locations and isograd locations from Figure 

2a,b. Uncertainities on temperature estimates of aureole rocks as above. See text for discussion of temperature estimates and uncertainties for the regional rocks at Ballachulish.

Figure 5. Scans of the rock thin sections for Nelson (top, a-f) and Ballachulish (bottom, g-l) in order of increasing metamorphic grade. Nelson a: 03-OC-9, b: 03-13, c: 93-5, d: 93-13, e: 93-16, f: 93-19a; Ballachulish g: 92-1A, h: 92-13, i: 94-19, j: 94-10, k: 92-19, 1: $92-$ 21. Sample locations for Nelson are shown in Figure $1 b, c$, and for Ballachulish in Figure 2a,b. Scale bar is $1 \mathrm{~cm}$.

Figure 6. Photomicrographs of rocks from outside the garnet isograd of the Nelson aureole (a: 03-OC-9; b: 03-yc-06), and from outside the cordierite isograd of the Ballachulish aureole (c: 94-1/4; d: 92-1a).

Figure 7. Representative Raman spectra for Nelson (a) and Ballachulish (b) with increasing contact metamorphism. For each spectrum, the first order $\left(1100-1700 \mathrm{~cm}^{-1}\right)$ and corresponding second order regions $\left(2400-3000 \mathrm{~cm}^{-1}\right)$ are presented. The first-order region gives an insight on the degree of graphitization and the second-order region on the 3D stacking of graphitic CM.

Figure 8. (a) Evolution of the R2 ratio with distance to the intrusion for the Nelson aureole. Note the progressive and continuous decrease of R2 towards the intrusion (error bar is standard deviation for $\mathrm{n}$ spectra, see text and Table 2). (b) Evolution of the R2 ratio with distance to the intrusion for the Ballachulish aureole (error bar is standard deviation for $\mathrm{n}$ spectra, see text and Table 3). In (a) and (b), R2 value of 0 indicates presence of pristine graphite (see text). 
1143 Figure 9. Comparison of temperatures between the various RSCM calibrations and petrology 1144 by calculating the difference between RSCM temperature and petrology temperature for 1145 each sample versus the distance to the intrusion for the Nelson aureole. Uncertainty for $1146 \quad$ RSCM thermometry is $\pm 50^{\circ} \mathrm{C}$ (see text).

1147 Figure 10. Comparison of RSCM temperatures versus reference temperatures standing for 1148 temperatures quantified by conventional petrology and thermal modelling (Nelson and 1149 Ballachulish, this study), mineral assemblage and pseudosections (aureole in Morocco 1150 by Delchini et al., 2016), mineral assemblage and conventional geothermobarometry 1151 (aureoles in Japan by Aoya et al., 2010), thermal modelling with input from 1152 conventional petrology and RSCM thermometry (aureole in Canada by Hilchie \& 1153 Jamieson, 2014). The 1:1 line is depicted as well as lines representing 1:1 $\pm 25^{\circ} \mathrm{C}$. 1154 Uncertainty for RSCM thermometry is $\pm 50^{\circ} \mathrm{C}$ (see text). 
Table 1. Whole rock compositions

$\begin{array}{lrr}\mathbf{W t} \% & \begin{array}{c}\text { Nelson } \\ \text { Average } \\ \text { Ymir argillite* }\end{array} & \begin{array}{c}\text { Ballachulish } \\ \text { Average } \\ \text { Ball. Slate^ }\end{array} \\ \mathrm{SiO}_{2} & 60.41 & 60.68 \\ \mathrm{TiO}_{2} & 0.93 & 0.84 \\ \mathrm{Al}_{2} \mathrm{O}_{3} & 20.10 & 19.94 \\ \mathrm{FeO} & 5.68 & 5.20 \\ \mathrm{MnO} & 0.08 & 0.05 \\ \mathrm{MgO} & 2.30 & 3.44 \\ \mathrm{CaO} & 1.06 & 0.12 \\ \mathrm{Na} \mathrm{O}_{2} \mathrm{O} & 1.53 & 1.50 \\ \mathrm{~K}_{2} \mathrm{O} & 4.17 & 3.80 \\ \mathrm{P}_{2} \mathrm{O}_{5} & 0.15 & 0.07 \\ \mathrm{LOI}_{\mathrm{Total}} & 3.09 & 3.82 \\ \mathrm{~S} & 99.51 & 99.46 \\ \mathrm{C} & 0.03 & 0.17 \\ & 0.31 & 0.65\end{array}$

Moles elements x 100; MnNCKFMASHT ( $C$ and P dropped; projected from pyrrhotite)

\begin{tabular}{|c|c|c|}
\hline $\mathrm{Si}$ & 100.55 & 100.98 \\
\hline $\mathrm{Ti}$ & 1.17 & 1.05 \\
\hline $\mathrm{Al}$ & 39.43 & 39.12 \\
\hline $\mathrm{Fe}$ & 7.82 & 6.71 \\
\hline $\mathrm{Mn}$ & 0.12 & 0.07 \\
\hline Mg & 5.70 & 8.54 \\
\hline $\mathrm{Ca}$ & 1.90 & 0.22 \\
\hline $\mathrm{Na}$ & 4.92 & 4.84 \\
\hline K & 8.85 & 8.07 \\
\hline Mg\# & 0.419 & 0.541 \\
\hline Mg\# (S) & 0.422 & 0.560 \\
\hline $\mathrm{Mg \# (S+Ti)}$ & 0.462 & 0.560 \\
\hline$A^{\prime}$ & 0.144 & 0.240 \\
\hline Mn\# & 0.008 & 0.004 \\
\hline Ca\# & 0.122 & 0.013 \\
\hline \multicolumn{3}{|c|}{$\mathrm{Mg} \#=\mathrm{Mg} /(\mathrm{Mg}+\mathrm{Fe})$} \\
\hline \multicolumn{3}{|c|}{$\mathrm{Mg} \#(\mathrm{~S})=\mathrm{Mg} /(\mathrm{Mg}+\mathrm{Fe})$, after projection from pyrrhotite } \\
\hline \multicolumn{3}{|c|}{$\mathrm{Mg} \#(\mathrm{~S}+\mathrm{Ti})=\mathrm{Mg} /(\mathrm{Mg}+\mathrm{Fe})$, after projection from pyrrhotite and ilmenite (not for Rt-bearing BS) } \\
\hline \multicolumn{3}{|c|}{$\mathrm{A}^{\prime}=(\mathrm{Al}-\mathrm{Na}-2 \mathrm{Ca}-3 \mathrm{~K}) / 2$} \\
\hline \multicolumn{3}{|c|}{$\mathrm{Mn \#}=\mathrm{Mn} /(\mathrm{Mn}+\mathrm{Fe}+\mathrm{Mg}+\mathrm{Ca}) \mathrm{Ca} \#=\mathrm{Ca} /(\mathrm{Mn}+\mathrm{Fe}+\mathrm{Mg}+\mathrm{Ca})$} \\
\hline \multicolumn{3}{|c|}{$\mathrm{Ca \#}=\mathrm{Ca} /(\mathrm{Mn}+\mathrm{Fe}+\mathrm{Mg}+\mathrm{Ca})$} \\
\hline
\end{tabular}


Table 2 - Nelson samples

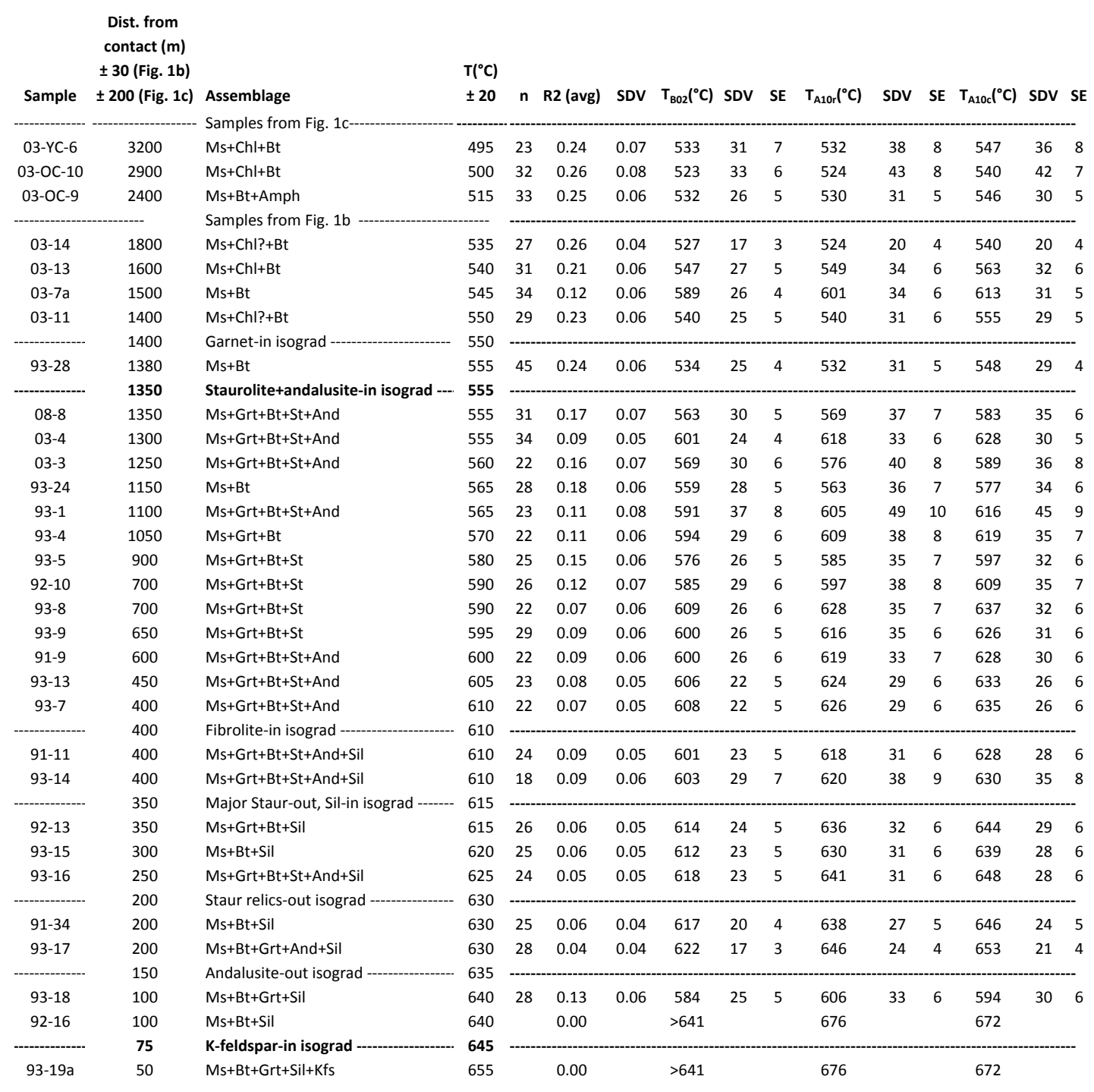

Total $=\mathbf{3 1}$ samples 
Table 3 - Ballachulish samples

\begin{tabular}{|c|c|c|c|c|c|c|c|c|c|c|c|c|c|c|c|c|c|}
\hline Sample & $\begin{array}{l}\text { Dist. from } \\
\text { contact (m) } \\
\pm 30 \text { (Fig. 2b) } \\
\pm 200 \text { (Fig. 2a) }\end{array}$ & Zone & Assemblage & $\begin{array}{l}\mathrm{T}\left({ }^{\circ} \mathrm{C}\right) \\
\pm 20\end{array}$ & $R / C$ & $\mathrm{n}$ & R2 (avg) & SDV & $\mathrm{T}_{\mathrm{BO} 2}\left({ }^{\circ} \mathrm{C}\right)$ & SDV & SE & $\mathrm{T}_{\mathrm{A} 10 \mathrm{r}}\left({ }^{\circ} \mathrm{C}\right)$ & SDV & SE & $\mathrm{T}_{\mathrm{A} 10 \mathrm{c}}\left({ }^{\circ} \mathrm{C}\right)$ & SDV & SE \\
\hline $92-63$ & 2800 & I (Grt zone) & Ms+Chl & 510 & $\mathrm{R}$ & 23 & 0.27 & 0.06 & 520 & 25 & 5 & 523 & 43 & 9 & 539 & 40 & 8 \\
\hline $92-1 \mathrm{~A}$ & 2500 & I (Grt zone) & $\mathrm{Ms}+\mathrm{Chl}$ & 500 & $\mathrm{R}$ & 24 & 0.21 & 0.05 & 547 & 20 & 4 & 549 & 25 & 5 & 564 & 24 & 5 \\
\hline $94-1 / 4$ & 2200 & I (Bt zone) & $\mathrm{Ms}+\mathrm{Chl}$ & 490 & $\mathrm{R}$ & 21 & 0.23 & 0.03 & 539 & 14 & 3 & 538 & 17 & 4 & 554 & 16 & 4 \\
\hline $92-65$ & 1600 & I (Grt zone) & $\mathrm{Ms}+\mathrm{Chl}$ & $510 / 530$ & $\mathrm{R} / \mathrm{C}$ & 23 & 0.25 & 0.05 & 532 & 22 & 5 & 530 & 27 & 6 & 545 & 26 & 5 \\
\hline $92-4 b$ & -1150 & $\begin{array}{c}\text {---- Start of } \\
1\end{array}$ & $\begin{array}{l}\text { samples from transect } \\
\mathrm{Ms}+\mathrm{Chl}\end{array}$ & 545 & C & 21 & 0.20 & 0.06 & 553 & 26 & 6 & 556 & 32 & 7 & 570 & 30 & 7 \\
\hline - & 1100 & ----- Cordieri & ite+biotite-in isograd ---. & 550 & & & & & & & & & & & & & \\
\hline $92-4 c$ & 1090 & II & $\mathrm{Ms}+\mathrm{Chl}+\mathrm{Crd}+\mathrm{Bt}$ & 550 & C & 22 & 0.19 & 0.05 & 556 & 24 & 5 & 559 & 30 & 6 & 573 & 28 & 6 \\
\hline $92-5$ & 1040 & ॥ & $\mathrm{Ms}+\mathrm{Chl}+\mathrm{Crd}+\mathrm{Bt}$ & 555 & C & 22 & 0.22 & 0.04 & 542 & 20 & 4 & 542 & 25 & 5 & 558 & 23 & 5 \\
\hline 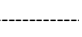 & 1000 & ----- Chlorite & -out isograd -- & 555 & & & & & & & & & & & & -..... & \\
\hline $92-8$ & 920 & III & $\mathrm{Ms}+\mathrm{Crd}+\mathrm{Bt}$ & 560 & C & 26 & 0.22 & 0.06 & 542 & 28 & 5 & 542 & 34 & 7 & 557 & 32 & 6 \\
\hline $92-9$ & 850 & III & $\mathrm{Ms}+\mathrm{Crd}+\mathrm{Bt}$ & 565 & C & 23 & 0.21 & 0.05 & 547 & 24 & 5 & 549 & 29 & 6 & 564 & 28 & 6 \\
\hline $92-10$ & 720 & III & $\mathrm{Ms}+\mathrm{Crd}+\mathrm{Bt}$ & 575 & $C$ & 25 & 0.20 & 0.07 & 550 & 30 & 6 & 552 & 38 & 8 & 567 & 35 & 7 \\
\hline $92-12$ & 650 & III & $\mathrm{Ms}+\mathrm{Crd}+\mathrm{Bt}$ & 580 & $C$ & 19 & 0.20 & 0.06 & 554 & 26 & 6 & 557 & 32 & 7 & 572 & 31 & 7 \\
\hline $94-4$ & 550 & III & $\mathrm{Ms}+\mathrm{Crd}+\mathrm{Bt}$ & 585 & $C$ & 21 & 0.21 & 0.05 & 549 & 22 & 5 & 551 & 28 & 6 & 566 & 26 & 6 \\
\hline $92-13$ & 550 & III & $\mathrm{Ms}+\mathrm{Crd}+\mathrm{Bt}$ & 585 & $C$ & 23 & 0.21 & 0.05 & 549 & 22 & 5 & 551 & 28 & 6 & 566 & 26 & 5 \\
\hline $94-5$ & 500 & III & $\mathrm{Ms}+\mathrm{Crd}+\mathrm{Bt}$ & 590 & C & 24 & 0.19 & 0.05 & 556 & 20 & 4 & 559 & 25 & 5 & 574 & 24 & 5 \\
\hline - & 450 & ----- Andalus & ite-in isograd ------ & 595 & - & & - & 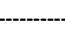 & & 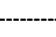 & & 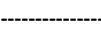 & & & & - & - \\
\hline $92-15$ & 430 & IV & $\mathrm{Ms}+\mathrm{Crd}+\mathrm{Bt}$ & 595 & C & 12 & 0.21 & 0.06 & 547 & 26 & 7 & 548 & 32 & 9 & 563 & 30 & 9 \\
\hline $93-15$ & 430 & IV & $\mathrm{Ms}+\mathrm{Crd}+\mathrm{Bt}$ & 595 & C & 21 & 0.22 & 0.06 & 545 & 26 & 6 & 546 & 33 & 7 & 561 & 31 & 7 \\
\hline $94-15$ & 380 & IV & $\mathrm{Ms}+\mathrm{Crd}+\mathrm{And}+\mathrm{Bt}$ & 600 & C & 29 & 0.24 & 0.04 & 536 & 19 & 4 & 535 & 23 & 4 & 550 & 22 & 4 \\
\hline $94-7$ & 330 & IV & $\mathrm{Ms}+\mathrm{Crd}+\mathrm{And}+\mathrm{Bt}$ & 605 & C & 32 & 0.23 & 0.07 & 540 & 29 & 5 & 540 & 36 & 6 & 555 & 34 & 6 \\
\hline $94-19$ & 330 & IV & $\mathrm{Ms}+\mathrm{Crd}+\mathrm{And}+\mathrm{Bt}$ & 605 & C & 27 & 0.22 & 0.06 & 542 & 27 & 5 & 543 & 33 & 6 & 558 & 31 & 6 \\
\hline $92-16$ & 300 & IV & $\mathrm{Ms}+\mathrm{Crd}+\mathrm{And}+\mathrm{Bt}$ & 610 & C & 26 & 0.19 & 0.07 & 556 & 29 & 6 & 560 & 37 & 7 & 574 & 35 & 7 \\
\hline $94-8$ & 250 & IV & $\mathrm{Ms}+\mathrm{Crd}+\mathrm{And}+\mathrm{Bt}$ & 620 & C & 27 & 0.19 & 0.06 & 555 & 25 & 5 & 558 & 32 & 6 & 573 & 30 & 6 \\
\hline $94-9$ & 240 & IV & $\mathrm{Ms}+\mathrm{Crd}+\mathrm{Bt}$ & 620 & C & 26 & 0.23 & 0.04 & 539 & 19 & 4 & 538 & 22 & 4 & 553 & 21 & 4 \\
\hline $92-17$ & 230 & IV & $\mathrm{Ms}+\mathrm{Crd}+\mathrm{And}+\mathrm{Bt}$ & 625 & C & 34 & 0.21 & 0.06 & 547 & 27 & 5 & 548 & 33 & 6 & 563 & 32 & 5 \\
\hline . & 220 & ---- K-feldsp & par-in isograd - --a- & 625 & -- & & 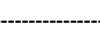 & 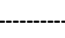 & & ו--ב- & & & & 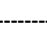 & & ---- & - \\
\hline $94-10$ & 210 & v & $\mathrm{Ms}+\mathrm{Crd}+\mathrm{And}+\mathrm{Bt}$ & 625 & C & 34 & 0.21 & 0.06 & 549 & 25 & 4 & 550 & 31 & 5 & 565 & 30 & 5 \\
\hline $94-11$ & 190 & v & $\mathrm{Crd}+\mathrm{And}+\mathrm{Kf} \mathrm{s}+\mathrm{Ms}+\mathrm{Bt}$ & 630 & C & 20 & 0.14 & 0.08 & 578 & 36 & 8 & 587 & 46 & 10 & 600 & 43 & 10 \\
\hline $92-18$ & 170 & v & $\mathrm{Crd}+\mathrm{And}+\mathrm{Kfs}+\mathrm{Ms}+\mathrm{Bt}$ & 640 & C & 35 & 0.21 & 0.06 & 549 & 28 & 5 & 551 & 35 & 6 & 566 & 33 & 6 \\
\hline $92-19$ & 130 & v & $\mathrm{Crd}+\mathrm{And}+\mathrm{Sil}+\mathrm{Kfs}+\mathrm{Ms}$ & 650 & C & 27 & 0.15 & 0.07 & 576 & 29 & 6 & 585 & 38 & 7 & 597 & 35 & 7 \\
\hline $92-20$ & 70 & v & $\mathrm{mig}+\mathrm{Crd}+\mathrm{Sil}+\mathrm{And}+\mathrm{Kfs}$ & 680 & C & & 0.00 & & $>641$ & & & 676 & & & 672 & & \\
\hline $92-21$ & 0 & v & $\mathrm{mig}+\mathrm{Crd}+\mathrm{Sil}+\mathrm{And}+\mathrm{Kfs}$ & 700 & C & & 0.00 & & $>641$ & & & 676 & & & 672 & & \\
\hline
\end{tabular}

Total $=\mathbf{2 9}$ samples

$\mathrm{C}=$ contact metamorphic

$\mathrm{R}=$ regional metamorphic

$\mathrm{mig}=$ rocks contain textures and structures suggestive of migmatisation (partial melting) 
Fig. 1
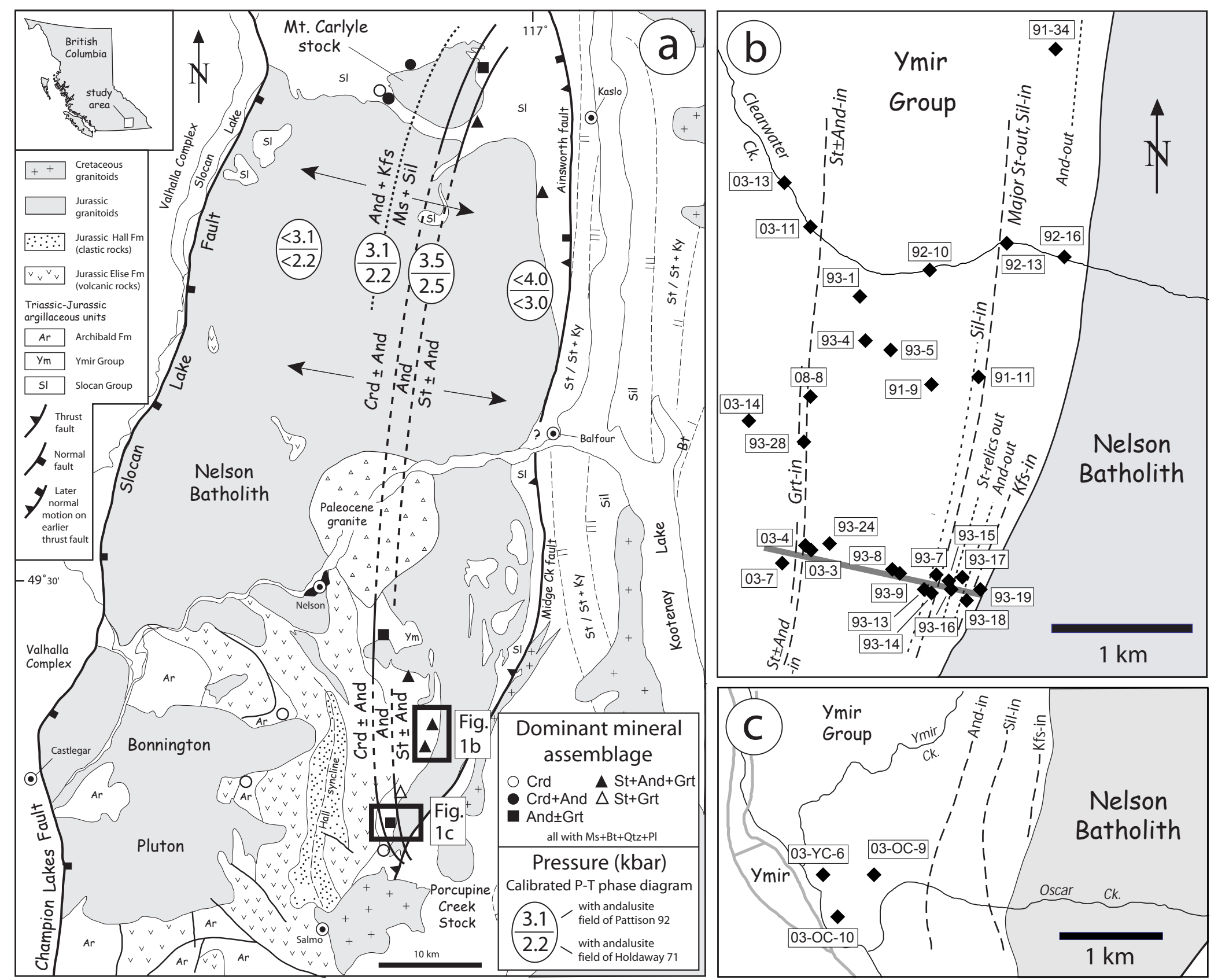
Fig. 2

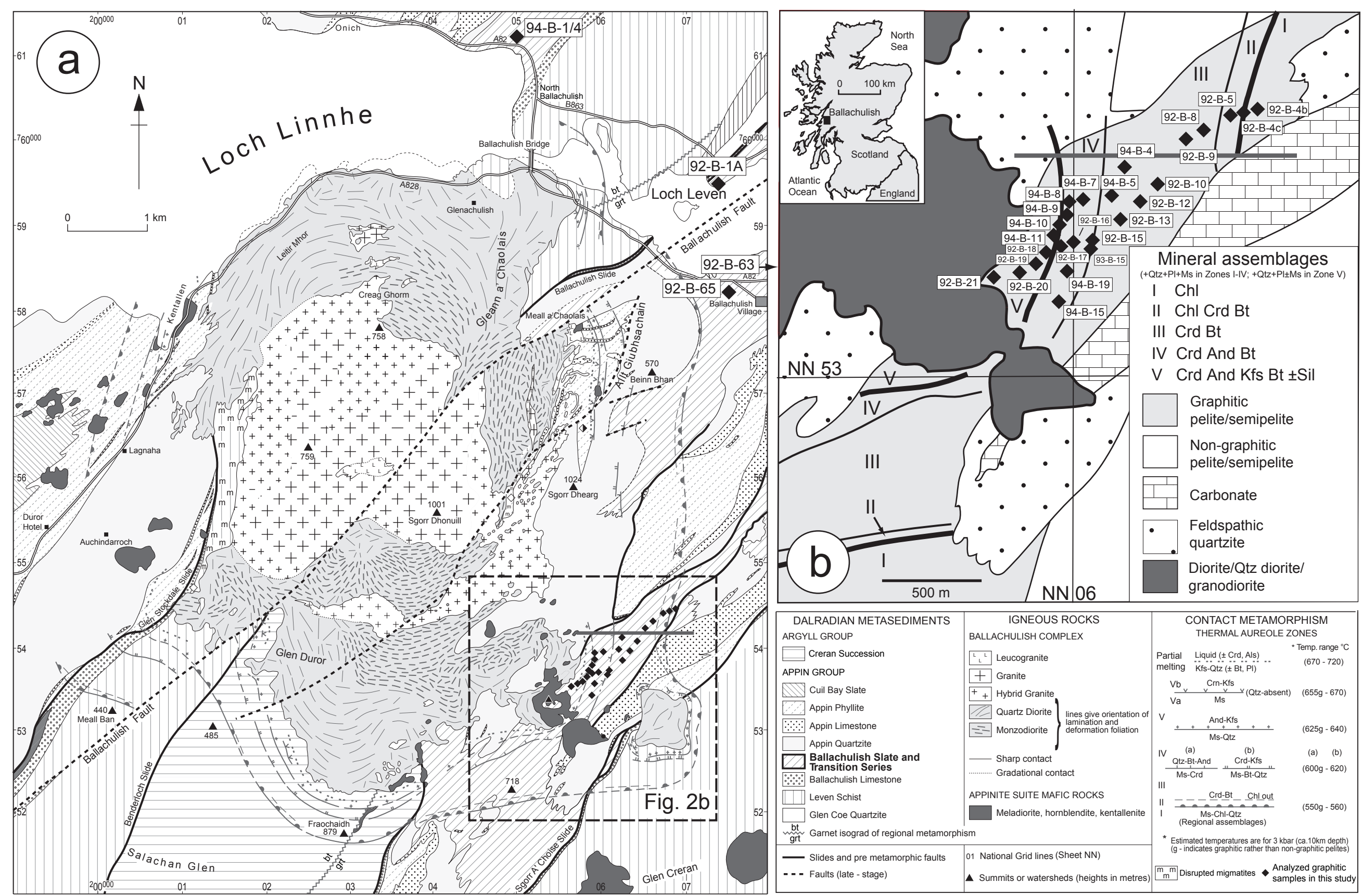


Fig. 3

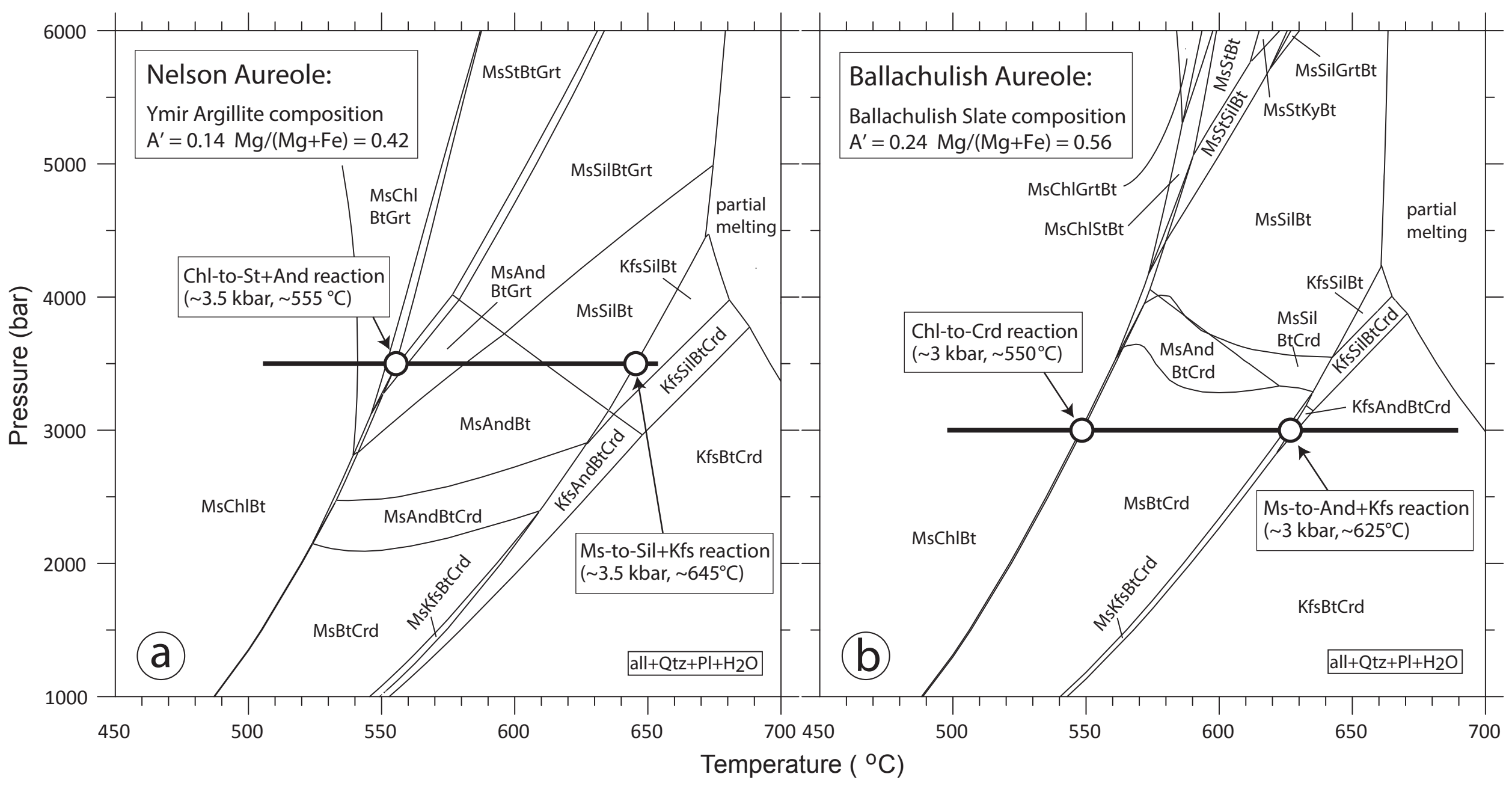


Fig. 4
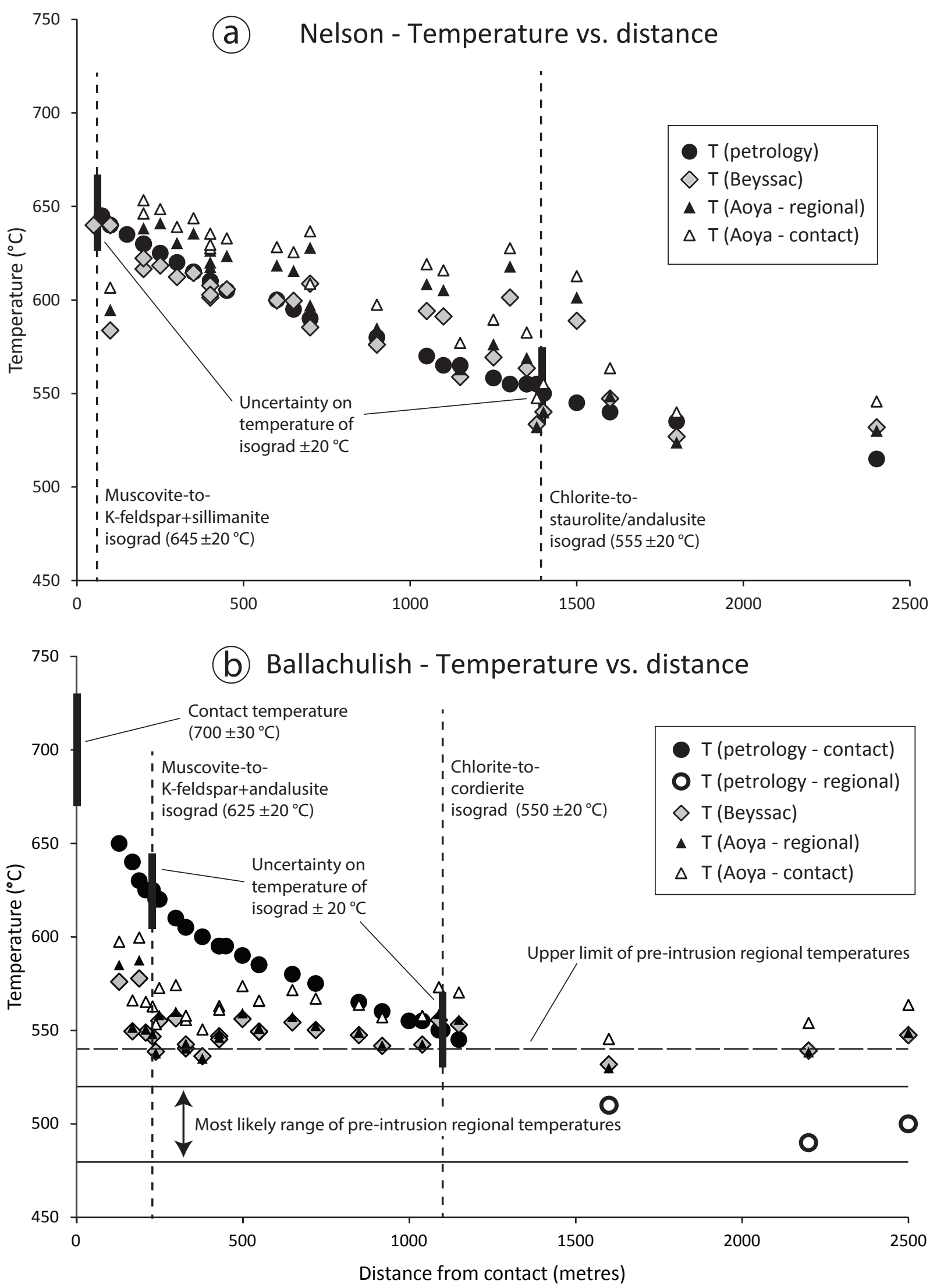

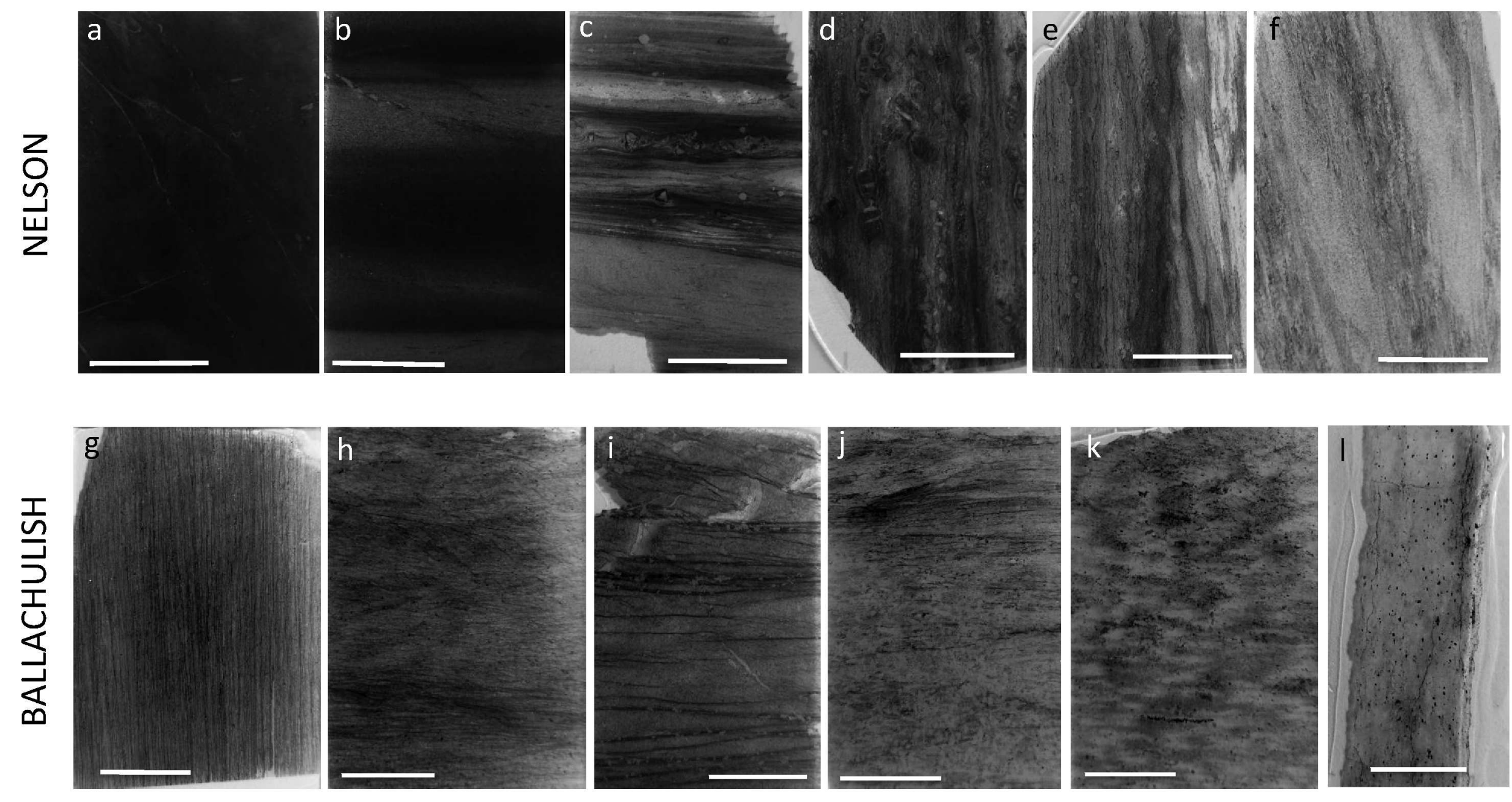

Increasing contact metamorphism

Fig 5 

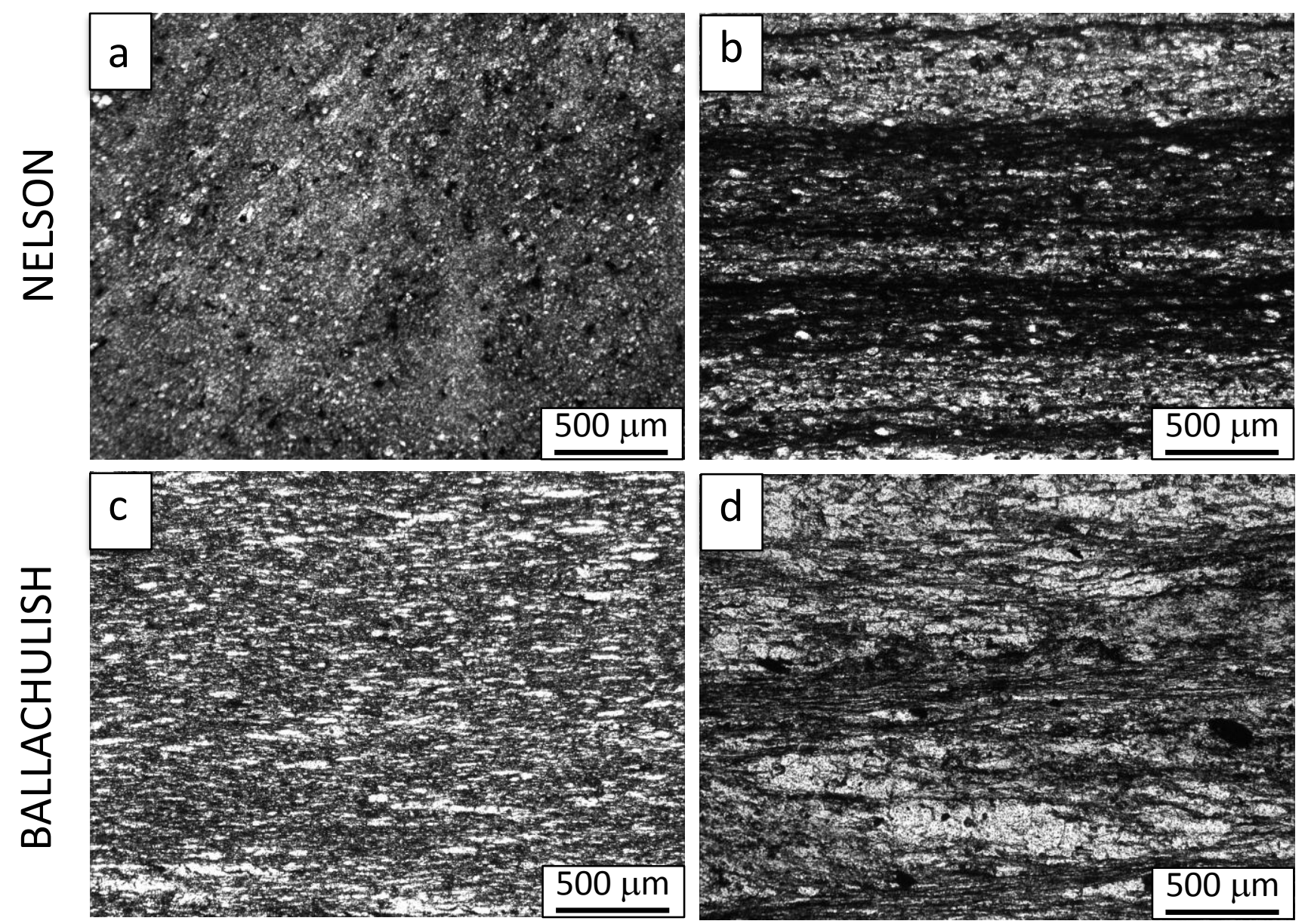

Fig 6 

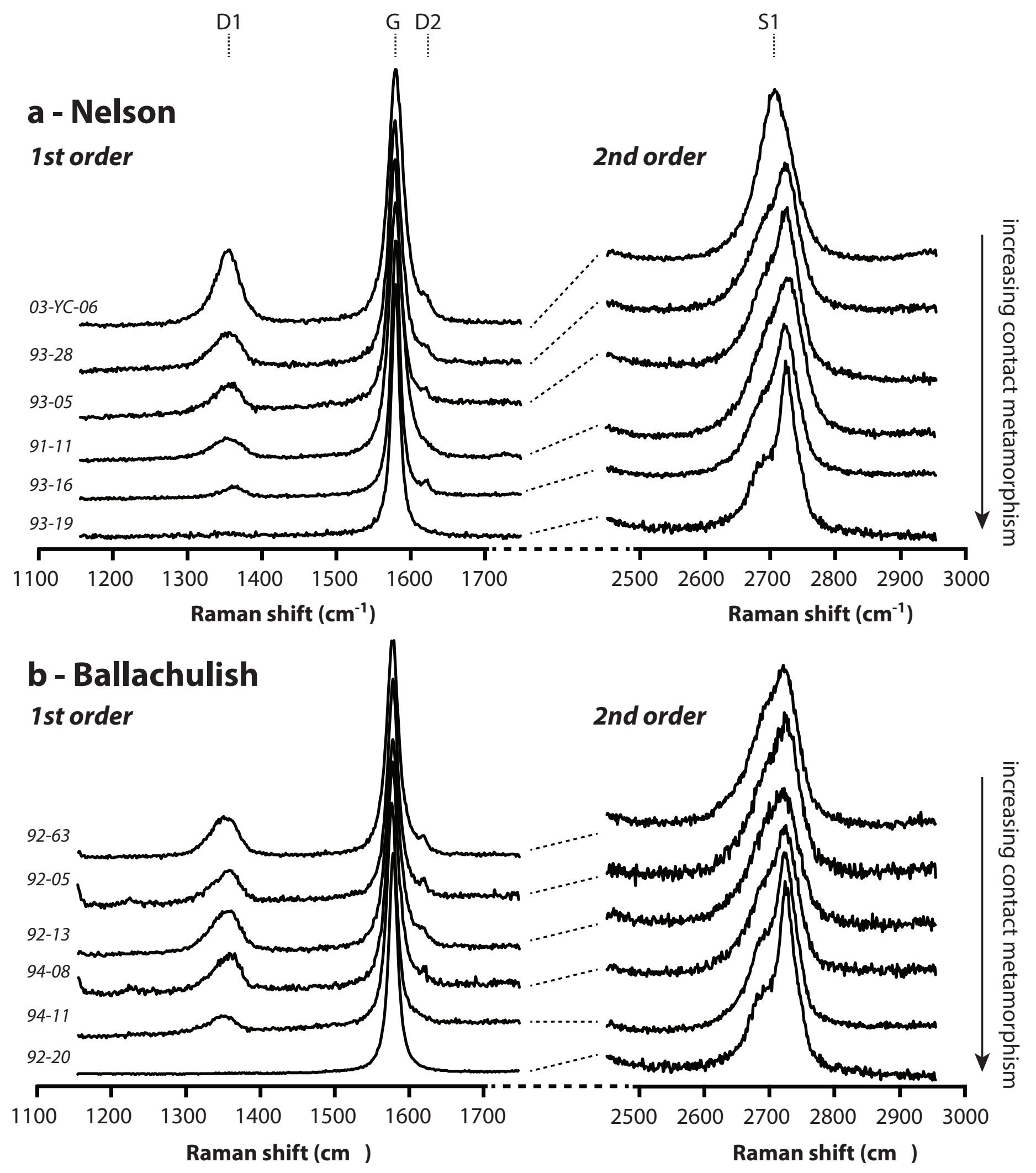

Fig 7 

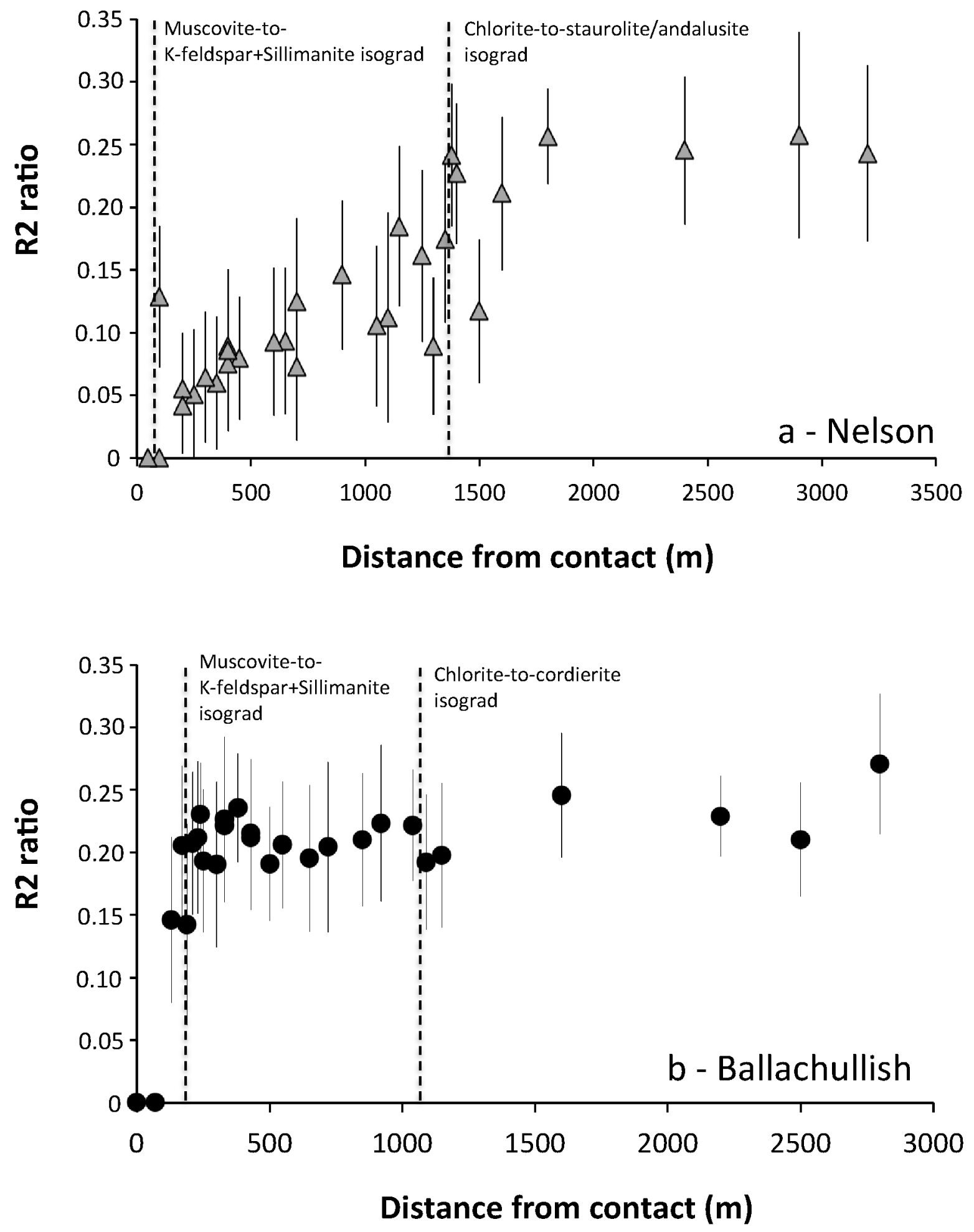

Fig 8 


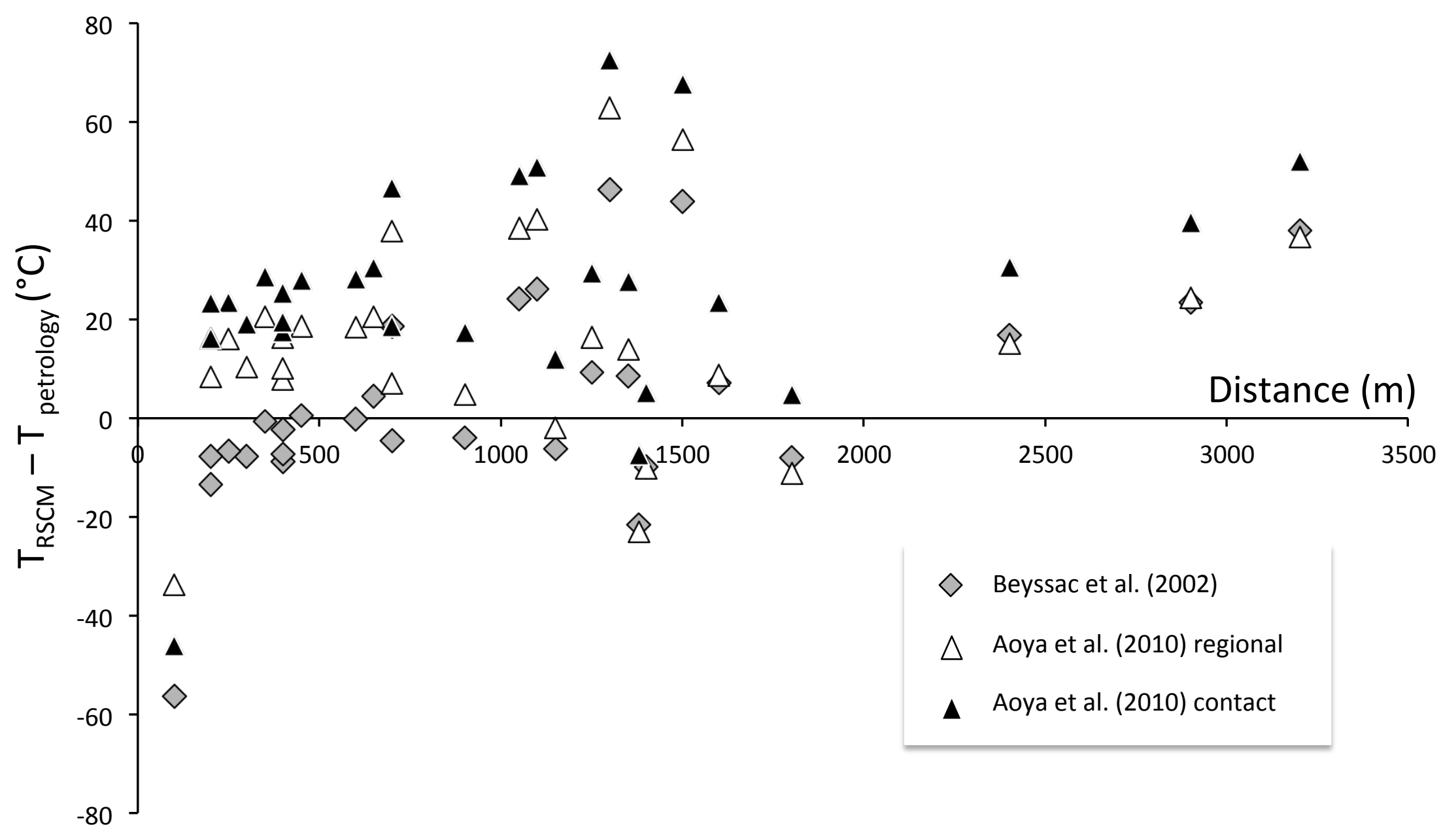

Fig 9 


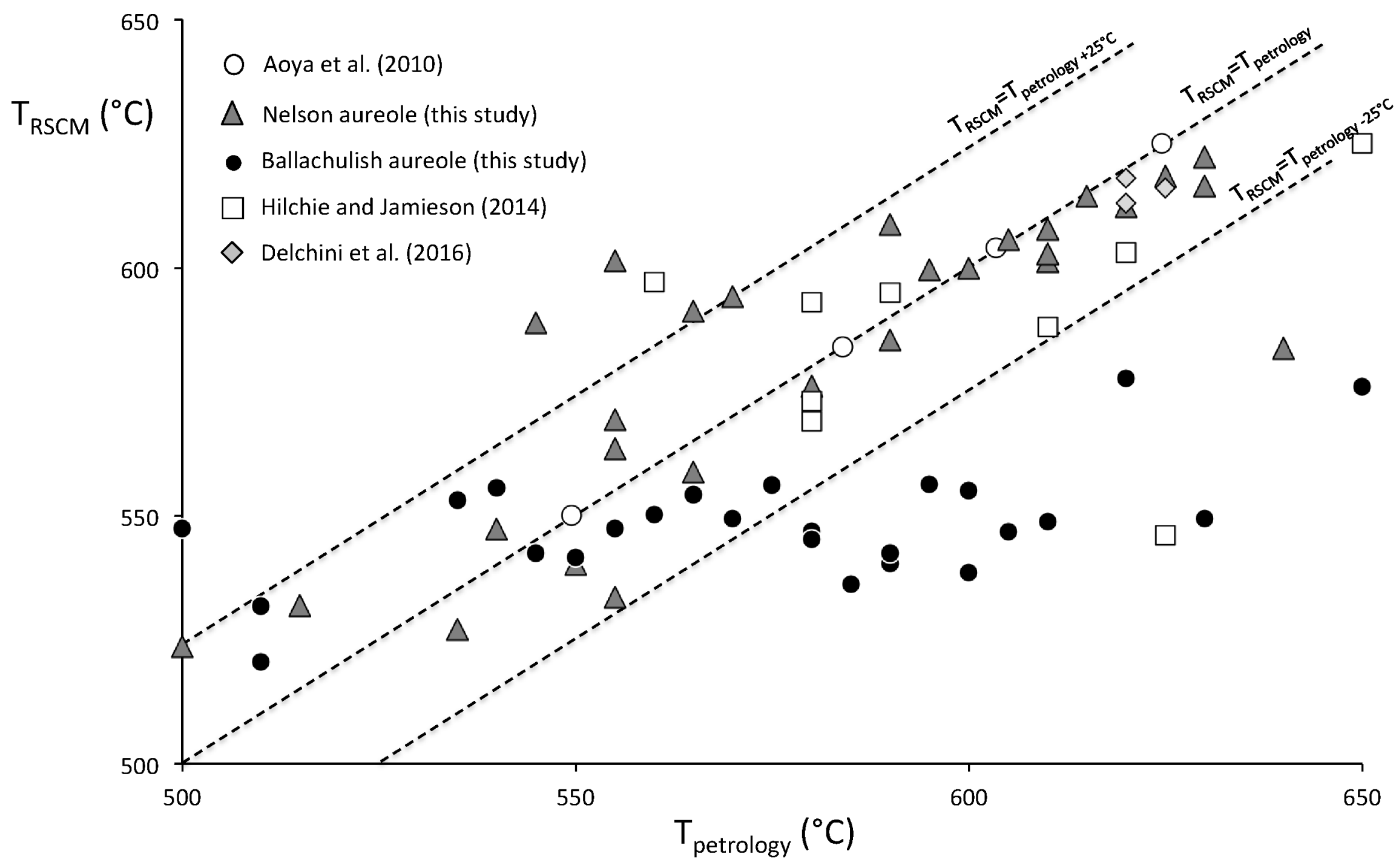

Fig 10 